\title{
Amyloid Beta Exposure on Olfactory Ensheathing Cells Induces Different Expression Pattern of Tissue Transglutaminase and Its Isoforms: Modulatory Effect of Indicaxanthin
}

\section{Agatina Campisi ( $\sim$ campisag@unict.it)}

University of Catania: Universita degli Studi di Catania https://orcid.org/0000-0002-9808-4681

\section{Giuseppina Raciti}

University of Catania: Universita degli Studi di Catania

\section{Giovanni Sposito}

University of Catania: Universita degli Studi di Catania

\section{Rosaria Grasso}

University of Catania: Universita degli Studi di Catania

\section{Maria Assunta Chiacchio}

University of Catania: Universita degli Studi di Catania

\section{Michela Spatuzza}

National Research Council: Consiglio Nazionale delle Ricerche

\section{Alessandro Attanzio}

University of Palermo: Universita degli Studi di Palermo

\section{Ugo Chiacchio}

University of Catania: Universita degli Studi di Catania

\section{Luisa Tesoriere}

University of Palermo: Universita degli Studi di Palermo

\section{Mario Allegra}

University of Palermo: Universita degli Studi di Palermo

\section{Rosalia Pellitteri}

National Research Council: Consiglio Nazionale delle Ricerche

\section{Research article}

Keywords: Tissue transglutaminase, Olfactory Ensheathing Cells, amyloid-beta, oxidative stress, Indicaxanthin, self-renewal

Posted Date: January 15th, 2021 
DOI: https://doi.org/10.21203/rs.3.rs-145818/v1

License: (c) (1) This work is licensed under a Creative Commons Attribution 4.0 International License. Read Full License 


\section{Abstract \\ Background}

Alzhèimer Disease (AD) is characterized by intracellular and extracellular protein aggregates in the brain, including amyloid-beta (A $\beta$ ). $A \beta$ is a substrate for tissue transglutaminase (TG2), an ubiquitarian calciumdependent protein that induces $A \beta$ oligomerization and aggregation. We assessed the effect of full native peptide of $A \beta(1-42)$, the fragments (25-35 and 35-25) on TG2 expression levels and its isoforms (Long and Short) on Olfactory Ensheathing Cells (OECs). The levels of cytoskeletal proteins, Vimentin and Glial Fibrillary Acid Protein (GFAP), were also studied. The effect of the pre-treatment with Indicaxanthin on cell viability, total Reactive Oxygen Species (ROS), superoxide anion $\left(\mathrm{O}_{2}{ }^{-}\right)$and apoptotic pathway activation was assessed. Since Nestin is co-expressed in pluripotent stem cells with cyclin $D_{1}$, their levels were evaluated.

\section{Methods}

Mouse primary OECs were exposed to $10 \mu \mathrm{MA}(1-42)$ or $A \beta(25-35)$ or $A \beta(35-25)$ for $24 \mathrm{~h}$ both in the absence and in the presence of Indicaxanthin. TG2 and its isoforms were evaluated through Confocal Laser Scanning Microscopy and Western Blot analysis. Data were statistically analysed using one-way analysis of variance followed by post hoc Holm-Sidak.

\section{Results}

Our findings highlight that OEC exposure to $A \beta(1-42)$ and its fragments induced an increase of TG2 levels and the different expression pattern of its isoforms. Indicaxanthin pre-treatment reduced TG2 overexpression differently modulating its isoforms, following $A \beta$ exposure of the cells. It was also able to prevent total ROS and $\mathrm{O}_{2}{ }^{-}$production, to reduce GFAP and Vimentin levels, inhibiting apoptotic pathway activation. It also leaded to an increase of Nestin and cyclin $D_{1}$ expression levels.

\section{Conclusions}

Our results show that $A \beta$ exposure on OECs induces an increase of TG2 levels and a different expression pattern of its isoforms and that Indicaxanthin pre-treatment stimulates OEC self-renewal through the reparative activity played by TG2. They also suggest that $A \beta$ in OECs, both in the absence and in the presence of Indicaxanthin, might differently induce the transition of TG2 between "closed" and "open" conformation, providing a new mechanism involved in the signal pathways activated by the protein in $A \beta$ injury important for neural regeneration of $A D$.

\section{Background}


Alzhèimer Disease $(A D)$ is characterized by intracellular and extracellular protein aggregates in the brain, including microtubule-associated protein tau and cleavage products of the amyloid precursor protein, amyloid-beta $(A \beta)$. The accumulation of $A \beta$ is responsible of oxidative stress, inflammation and neurotoxicity, that lead to apoptosis and the deterioration of the neurotransmission system observed in $A D$ [1]. $A \beta$ is also a substrate for tissue transglutaminase (TG2), an ubiquitarian calcium-dependent protein that catalyses cross-linking reactions, inducing $A \beta$ oligomerization and aggregation, which are typical signs of AD [2]. It also has disulfide isomerase [3], kinase and GTPase activities [4]. TG2 is mainly localized in the cytosol (73\%), partially in the plasma membrane (20\%), nucleus $(7 \%)$, and the extracellular matrix [5-7]. The functions of TG2 depend on its intracellular localization. When it is localized in the cytosol, TG2 controls apoptotic processes in a stimuli-dependent manner, through its transamidating activity that is necessary for pro-apoptotic effects [6]. Instead, when TG2 is localized into the nuclear compartment, it phosphorylates different proteins, including retinoblastoma and p53, that are known to be substrates for TG2 kinase activity [8]. Furthermore, TG2 is present in two isoforms: short TG2 (TG2-S) and long TG2 (TG2-L), having different cellular localization that mediate opposite cellular functions [9-11]. In particular, TG2-S, localized in the cytosol and mitochondria, increases during apoptosis, is responsible of the aggregate formation and involved in AD [9-11]. In contrast, TG2-L, localized in the nucleus, exerts a protective effect against cellular injury and apoptosis due to its transamidanting activity [9-11].

Several findings reported that in AD patients an early sign of neurodegeneration is represent by a reduced function of olfactory performance [12]. In particular, a peculiar olfactory glial cell is represented by Olfactory Ensheathing Cells (OECs). This cellular type, showing a bipolar or multipolar morphology, surrounds the olfactory nerves, is able to secrete different growth factors, neurotrophins, adhesion molecules and numerous markers, which promote neuron survival and axonal growth, supporting also injured Central Nervous System [13-16]. OECs are able to stimulate angiogenesis and remyelination, therefore they play an important role in transplants in spinal cord injury [17]. In addition, OECs exhibit stem cell properties, expressing Nestin, a marker of precursor neural stem cells [17]. In previous researches we demonstrated that TG2 was overexpressed in OECs exposed to full native peptide $A \beta(1-$ $42)$ and $A \beta(25-35)$ fragment and that some growth factors were able to down-regulate the expression levels of the protein [18].

In the recent years, growing attention rose on neuro-nutraceutics, such as Indicaxanthin, a phytochemical produced by cactus pear fruit from Opuntia ficus-indica, L. Mill. [19, 20]. Indicaxanthin possesses significant anti-proliferative, antitumor and anti-inflammatory effects both in vivo and in vitro [21, 22]. In addition, it modulates reactive oxygen species (ROS) production, prevents mitochondrial damage, regulates cell redox balance and calcium homeostasis in a number of experimental in vitro models [23]. Interestingly enough, and in contrast with the majority of phytochemicals, Indicaxanthin is able to cross the blood brain barrier and to modulate the bioelectric neuronal activity in the hippocampus [24].

Herein, we assessed TG2, TG2-S and TG2-L expression levels in OECs exposed to $A \beta(1-42)$ or $A \beta(25-35)$ or reverse-sequence fragment $A \beta(35-25)[25]$ and the effect of Indicaxanthin. The expression levels of 
some cytoskeletal proteins, such as Vimentin, marker of gliosis and also substrate of TG2, Glial Fibrillary Acid Protein (GFAP), glial marker of growth, maturation and differentiation, were evaluated. Since Nestin, marker of neural precursors, is co-expressed in pluripotent stem cells with cyclin $D_{1}$ [26], marker of cellular proliferation, the effect of Indicaxanthin pre-treatment on their levels was tested. Furthermore, its effect on OECs exposed to $A \beta(1-42), A \beta(25-35)$ and $A \beta(35-25)$ on cell viability, on the production of total Reactive Oxygen Species (ROS), superoxide anion $\left(\mathrm{O}_{2}{ }^{-}\right)$and on apoptotic pathway activation were assessed.

\section{Methods}

\section{Materials}

Leupeptin, aprotinin, Phenylmethylsulfonyl Fluoride (PMSF), EDTA, EGTA, Sodium Dodecyl Sulfate (SDS), phosphatase inhibitor cocktail II, cytosine arabinoside, full native peptide of $A \beta(1-42)$, fragment $A \beta(25-$ 35), fragment $A \beta(35$ - 25), 3(4,5-dimethyl-thiazol-2-yl)2,5-diphenyl-tetrazolium bromide (MTT), Dimethyl sulfoxide (DMSO), Lab-Tek II Chamber-Slide Systems, paraformaldehyde and others analytical chemicals were purchased from Sigma-Aldrich (Milan, Italy). Acetic acid and methanol were of LC grade and purchased from Merck (Milan, Italy). Trypsin, antibiotics, heat inactivated Foetal Bovine Serum (GIBCO), Phosphate Buffer Saline solution (PBS), Normal Goat Serum (NGS, GIBCO), Modified Eagle Medium (MEM) with $2 \mathrm{mM}$ GlutaMAX (GIBCO), Nitrocellulose Membrane Filter Paper Sandwich $0.45 \mu \mathrm{m}$ pore size (Invitrogen), mouse monoclonal antibody against $\beta$-tubulin, anti-rabbit IgG horseradish peroxidaseconjugated and anti-mouse IgG horseradish peroxidase-conjugated were from Thermo Fisher Scientific (Milan, Italy). Bicinconinic acid method (Pierce/Thermo-Scientific, Rockford, IL). Mini-PROTEAN® TGX ${ }^{\mathrm{TM}}$ Precast Protein Gels (4-15\%), Mini Trans Blots Filter Paper, 10X Tris/Glycine/SDS buffer, 10X Tris/Glycine buffer, 4x Laemmli Sample Buffer, 2-mercaptoethanol, Precision Plus Protein ${ }^{\text {TM }}$ Standard Dual Color, were from Bio-Rad Laboratories Srl (Milan, Italy). Rabbit monoclonal antibody against Cyclin $D_{1}$ was from Millipore (Milan, Italy). Mouse monoclonal antibody against TG2 (Neomarkers), mouse monoclonal antibody against Nestin and cellular ROS/Superoxide Detection Assay were from Abcam (Milan, Italy). Mouse monoclonal antibody against GFAP and mouse monoclonal antibody against Vimentin were from DAKO. Mouse monoclonal antibody against caspase-3 was from Becton-Dickinson (Milan, Italy). Cy3 goat anti-mouse and Fluorescein Isothiocyanate (FITC)-conjugated goat anti-mouse IgG antibody were from Jackson Immunological Research Laboratories Inc. Western Lightning Plus-ECL Enhanced Chemiluminescence Substrate was from Perkin-Helmer (Monza, Italy).

\section{Animals}

Experiments were carried out on 2-day-old mouse pups (P2), provided by Envigo RMS s.r.l. (Italy). Animals were kept in a controlled environment $\left(23 \pm 1^{\circ} \mathrm{C}, 50 \pm 5 \%\right.$ humidity) with a $12 \mathrm{~h}$ light/dark cycle with food and water available ad libitum. Experiments were carried out in compliance with the Italian law on animal care no. $116 / 1992$ and in accordance with the European Community Council Directive (86/609/EEC) and 
were approved by the Ethical Committee at the University of Catania (Italy). Efforts were made to minimize the number of animals used.

\section{OEC cultures}

Olfactory bulbs were removed from decapitated pups and placed in cold $\left(+4^{\circ} \mathrm{C}\right)$ Leibowitz L-15 medium [27]. Successively, pellets were digested in MEM-H, containing collagenase and trypsin mixture. Trypsinization was stopped by adding DMEM supplemented with $10 \%$ FBS (DMEM/FBS). Cells were resuspended and plated in flasks fed with complete DMEM/FBS. Cytosine arabinoside $\left(10^{-5} \mathrm{M}\right)$, an antimitotic agent, was added $24 \mathrm{~h}$ after initial plating, in order to reduce the number of dividing fibroblasts. OECs were then processed to an additional step transferring from one flask to a new one, in order to reduce contaminating cells, following the method by Chuah and Au [28]. When OECs were confluent, they were removed by trypsin, transferred on $25 \mathrm{~cm}^{2}$ flasks and cultured in DMEM/FBS. Cells were then incubated at $37^{\circ} \mathrm{C}$ in complete medium and fed twice a week. Purified OECs were grown in DMEM/FBS on $14 \mathrm{~mm}$ diameter glass coverslips and 96 multiwells flat bottomed at a final density of $1 \times 10^{4}$ cells/coverslip and on $25 \mathrm{~cm}^{2}$ flasks at a final density of $1 \times 10^{6}$. Cells were then incubated at $37^{\circ} \mathrm{C}$ a humidified $5 \% \mathrm{CO}_{2}-95 \%$ air mixture.

\section{Indicaxanthin purification}

Indicaxanthin was isolated from Opuntia ficus indica L. Mill fruit pulp (yellow cultivar) and purity (97\%) of the pigment was assessed by HPLC according to a previous described method [24].

\section{Treatment of OECs}

OECs were divided in different groups: a group was stressed for $24 \mathrm{~h}$ with of $10 \mu \mathrm{M} A \beta(1-42)$ or $A \beta(25-$ $35)$ or $A \beta(35-25)$ [18]; another group was treated with $50 \mu \mathrm{M}$ or $100 \mu \mathrm{M}$ of Indicaxanthin for $24 \mathrm{~h}$; other two groups were pre-treated with $50 \mu \mathrm{M}$ or $100 \mu \mathrm{M}$ of Indicaxanthin for $30 \mathrm{~min}$ and subsequently were exposed to $10 \mu M A \beta(1-42)$ or $A \beta(25-35)$ or $A \beta(35-25)$. Stock solutions of full native peptide $A \beta(1-42)$, $A \beta(25-35)$ and $A \beta(35-25)$ fragments were diluted in DMSO. For every test, the suitable aliquot from each stock solution was added to culture medium, in order to obtain final concentration $10 \mu \mathrm{M}$. A group of cells was treated with a corresponding volume of PBS (final concentration $2 \% \mathrm{v} / \mathrm{v}$ ) and used as control. Another group of cell cultures was treated with the corresponding volume of DMSO used to solubilize full native peptide $A \beta(1-42)$ and $A \beta$ fragments, having a final DMSO concentration of $2 \% \mathrm{v} / \mathrm{v}$.

\section{MTT Bioassay}

In untreated and treated OECs, $20 \mu$ of $0.5 \%$ MTT solution were added to each multiwell as previous reported [18]. After $2 \mathrm{~h}$ of incubation at $37^{\circ} \mathrm{C}$, the supernatant was removed, replaced with $200 \mu \mathrm{DMSO}$ and incubated at $37^{\circ} \mathrm{C}$ for $1 \mathrm{~h}$. The optical density of each well sample was measured with a microplate spectrophotometer reader (Titertek Multiskan; Flow Laboratories, Helsinki, Finland) at $\lambda=570 \mathrm{~nm}$. On the basis of MTT test, we chose as optimal concentration of Indicaxanthin to treat OECs both in the absence and in the presence of $10 \mu \mathrm{M} \mathrm{A} \beta(1-42), A \beta(25-35) A \beta(25-35), 100 \mu \mathrm{M}$ for $24 \mathrm{~h}$. 


\section{Total $\mathrm{ROS} / \mathrm{O}_{2}^{-}$production}

In untreated and treated OECs, total ROS and $\mathrm{O}_{2}{ }^{-}$production were assessed through Cellular ROS/Superoxide Detection Assay, according to manufacturer's instruction. The fluorescent products generated by the two dyes green for total intracellular ROS and orange for $\mathrm{O}_{2}{ }^{-}$detection were visualized using a wide-field Zeiss fluorescent microscope (Zeiss, Germany) equipped with standard green $\left(\lambda_{\mathrm{Ex}} / \lambda_{\mathrm{Em}}\right.$ $=490 / 525 \mathrm{~nm})$ and orange $\left(\lambda_{\mathrm{Ex}} / \lambda_{\mathrm{Em}}=550 / 620 \mathrm{~nm}\right)$ filter set.

\section{Immunocytochemical technique and CLSM analysis}

To assess the positivity for Vimentin (proliferation marker), GFAP (differentiation marker), caspase-3 (apoptotic marker), and TG2 in untreated and treated, OECs were processed through immunocytochemical procedures. After $24 \mathrm{~h}$ all cells were fixed through $4 \%$ paraformaldehyde in $0.1 \mathrm{M}$ PBS for $30 \mathrm{~min}$ and then were incubated overnight at $4{ }^{\circ} \mathrm{C}$ in the following primary antibodies: mouse monoclonal antibody against Vimentin (1:50), mouse monoclonal antibody against GFAP (diluted 1:1000), mouse monoclonal antibody against Nestin (1:200), mouse monoclonal antibody against Caspase-3 (1:500) and mouse monoclonal antibody against TG2 (1:200). FITC anti-mouse (diluted 1:200) and Cy3 anti-mouse (diluted 1:500) were used as secondary antibodies for $1 \mathrm{~h}$ at room temperature and in dark condition. Successively, coverslips were washed in PBS and mounted with PBS/glycerol. The immunostained coverslips were analysed on a Zeiss fluorescent microscope (Zeiss, Germany) and images were captured with an Axiovision Imaging System for GFAP, Nestin, Vimentin and caspase-3. The immunostained for TG2 was obtained using a Confocal Laser Scanning Microscope (CLSM) 510 Meta (Zeiss, Germany), using a X63 lens and captured with an Axiovision Imaging System [6, $18,29]$. The positive labeled cells were counted in ten different microscopic fields (20X magnification) and the positivity for each marker was expressed as percentage and compared with each respective control. No non-specific staining of OECs was observed in control incubations in which the primary antibodies were omitted. To analyze TG2 positive cells Confocal Laser Scanning Microscope (CLSM, LSM-510 Meta, Zeiss, Germany) was used. For the acquisition with CLSM, we used an Apo 63 x/1.4 oil immersion objective and the Argon $(\lambda=488 \mathrm{~nm})$ and $\mathrm{HeNe}(\lambda=543 \mathrm{~nm})$ lasers. Images were acquired at the pixel resolution of $1024 \times 1024$ and were processed to enhance brightness and contrast using the software ZEN 2009. The version number for software ZEN 2009 was 5.5.0.452 and provided together ZEISS confocal microscope. The ZEN 2009 soft version is avaible at link https://www.softpedia.com/get/Multimedia/Graphic/Graphic-Viewers/ZEN-2009-Light Edition.shtml. The optical fields were examined through green fluorophore excitation.

\section{Isolation of total protein and Western blot analysis}

Untreated and treated OECs cells were harvested in cold PBS, collected by centrifugation, resuspended in cell lysis buffer containing $50 \mathrm{mM}$ Tris- $\mathrm{HCl}$ (pH 6.8), $150 \mathrm{mM} \mathrm{NaCl}, 1 \mathrm{mM}$ EDTA, $0.1 \mathrm{mM} \mathrm{PMSF}, 10 \mu \mathrm{g} / \mathrm{mL}$ of aprotinin, leupeptin, pepstatin, incubated for $30 \mathrm{~min}$ at $4{ }^{\circ} \mathrm{C}$, centrifuged at $12,000 \mathrm{x} \mathrm{g}$ for $10 \mathrm{~min}$ at $4{ }^{\circ} \mathrm{C}$ and the supernatants containing total cell proteins were collected $[5,18,30,31]$. Briefly, extracted proteins 
were stored at $-80^{\circ} \mathrm{C}$, and protein quantitation was performed by bicinconinic acid method, according to to manufacturer's instruction. $40 \mu \mathrm{g}$ of total proteins were separated through $4-15 \%$ precast SDSpolyacrylamide gels and transferred to nitrocellulose membranes. Filters obtained were then incubated with the following 1:1000 diluted antibodies: mouse monoclonal antiboby against TG2, rabbit monoclonal antibody against Cyclin $D_{1}$, mouse monoclonal antibody against $\beta$-tubulin. Anti-rabbit lgG horseradish peroxidase-conjugated and anti-mouse IgG horseradish peroxidase-conjugated were then used. The expression of each protein was visualized through Western Lightning Plus-ECL Enhanced Chemiluminescence Substrate after autoradiography filter exposure. Blots were then scanned and quantified through ChemiDoc Imaging System (ChemiDoc ${ }^{\text {TM }}$ Imaging System, Bio-Rad, Milan). Densitometric analysis was performed through the integrated software and data obtained were normalized with $\beta$-tubulin.

\section{Statistical analysis}

Data were statistically analysed using one-way analysis of variance (one-way ANOVA) followed by post hoc Holm-Sidak test to calculate significant differences among groups. Data were reported represent the mean \pm S.D. of five separated experiments in triplicate, and differences among groups were considered to be significant at * $p<0.05$.

\section{Results}

\section{Cell viability}

To monitor cell viability in OECs unexposed and exposed to full native peptide $A \beta(1-42)$ or to the fragments $A \beta(25-35)$ and $A \beta(35-25)$ [18], both in the absence and in the presence of Indicaxanthin, MTT test was performed. In previous our studies we showed that the optimal concentration of $A \beta(1-42)$, $A \beta(25-35)$ and $A \beta(35-25)$ was $10 \mu \mathrm{M}$ for $24 \mathrm{~h}$ [18]. No significant differences between PBS and DMSOtreated OECs were observed, thus they were used as controls. A significant decrease in the percentage of cell viability in OECs exposed to $10 \mu \mathrm{M} A \beta(1-42)$ or $A \beta(25-35)$ was found, when compared with controls (Fig. 1). The reverse sequence of $A \beta(35-25)$ did not show any effect on cell viability, when compared with the controls (Fig. 1). No significant changes in the percentage cell viability were observed in OECs exposed to $50 \mu \mathrm{M}$ (Fig. 1B) and $100 \mu \mathrm{M}$ (Fig. 1C) of Indicaxanthin, when compared with the controls (Fig. 1A). The pre-treatment of OECs with $50 \mu \mathrm{M}$ and $100 \mu \mathrm{M}$ of Indicaxanthin and the subsequent exposure to $10 \mu \mathrm{M} \mathrm{A} \beta(1-42)$ or $A \beta(25-35)$ for $24 \mathrm{~h}$ was able to restore cell viability to the levels observed in the controls (Fig. 1B, C). Indicaxanthin pre-treatment did not induce any significant changes in OECs exposed to $A \beta(35-25)$ fragment.

Thus, for the following studies OECs were pre-treated with $100 \mu \mathrm{M}$ of Indicaxanthin for 30 min and subsequently exposed to native peptide $10 \mu \mathrm{M} \mathrm{A} \beta(1-42)$ or to the fragments $A \beta(25-35)$ or $A \beta(35-25)$ for $24 \mathrm{~h}$.

\section{Vimentin and GFAP immunolabeling}


To identify glial reactivity after the treatment of OECs exposed to the full native peptide $A \beta(1-42)$ or to $A \beta(25-35)$ or $A \beta(35-25)$ fragments both in the absence and in the presence of Indicaxanthin, we performed immunostaining using antibodies against cytoskeletal proteins Vimentin and GFAP. The exposure of the cells to $A \beta(1-42)$ or $A \beta(25-35)$ was able to induce a notable increase in the number of cells positive to Vimentin (Fig. 2) and GFAP (Fig. 3), when compared with the control cultures and those treated with the fragment $A \beta(35-35)$. In particular, the effect appeared more evident in $A \beta(25-35)$ exposed OECs, when compared with $A \beta(1-42)$ ones. The treatment of cultures with $100 \mu \mathrm{M}$ of Indicaxanthin did not induce changes for the positivity of the cells for Vimentin and GFAP, when compared with the controls. When the cells were pre-treated with Indicaxanthin and then exposed to $A \beta(1-42)$ or $A \beta(25-35)$, the cell positivity for Vimentin and GFAP appeared similar to those observed in control cultures. No specific staining of OECs was observed in control incubation in which the primary antibodies were omitted. This group of experiments demonstrated that full native peptide $A \beta(1-42)$ and fragment $A \beta(25-35)$ induced glial activation and that Indicaxanthin pre-treatment was able to counteract it.

\section{Total ROS/O${ }^{-}$generation}

To monitor the intracellular oxidative status, the staining of total intracellular ROS levels (Fig. 4A, green) and $\mathrm{O}_{2}{ }^{-}$(Fig. 4B, red) generation in OECs exposed for $24 \mathrm{~h}$ to the full native peptide $A \beta(1-42)$ or to the fragment $A \beta(25-35)$ or to $A \beta(35-25)$ both in the absence and in the presence of Indicaxanthin, was assessed. $A \beta$ treatment induced a significant increase in total ROS and $\mathrm{O}_{2}^{-}$levels, when compared with the controls. No significant change in total ROS and $\mathrm{O}_{2}^{-}$production in $\mathrm{A} \beta(35-25)$ and Indicaxanthin alone exposed cells was found. The OEC pre-treatment with Indicaxanthin and the subsequently exposure to $A \beta(1-42)$ or to $A \beta(25-35)$ or to $A \beta(35-25)$ induced a strong reduction both of total intracellular ROS and $\mathrm{O}_{2}{ }^{-}$levels. These findings highlighted that $A \beta(1-42)$ and $A \beta(25-35)$ increased the levels of total ROS and $\mathrm{O}_{2}$ - production and that Indicaxanthin pre-treatment was able to restore the oxidative status modified by $A \beta$ to control values, reducing prevalentely $\mathrm{O}_{2}{ }^{-}$generation.

\section{Total TG2 expression through immunocytochemistry}

The Fig. 5 reports TG2 positivity and its localization performed on single cell through immunocytochemical procedures and CLSM analysis. In the control cells a low staining for TG2 was found and the protein was prevalently localized in the cytosol. A more intense staining for TG2 both in $A \beta(1-42)$ and $A \beta(25-35)$ treated OECs was observed widely in the cytosol, when compared with the controls. In particular, the positivity of the cells for TG2 appeared more evident in $A \beta(25-35)$ treated ones, when compared with the controls and $A \beta(1-42)$ treated OECs. The exposure to the fragment $A \beta(35-25)$ produced a light increase for TG2 cell positivity, when compared with the controls and the protein appeared prevalently localized in the cytosol. In $100 \mu \mathrm{M}$ Indicaxanthin-treated cells, TG2 staining was slightly higher than controls and it was widely localized in the cytosol. In contrast, in the cells exposed to $A \beta(1-42)$ and $A \beta(25-35)$, Indicaxanthin pre-treatment was able to decrease the number of positive cells for TG2, when compared with the controls. Specifically, in Indicaxanthin treated OECs and subsequently 
exposed to $A \beta(1-42), T G 2$ was localized into the nucleus. Differently in $A \beta(25-35)$-Indicaxanthin pretreated cells, the protein was prevalently localized in the cytosol, even if some cells showed a low positivity for the protein in the nucleus and nucleoli. A low staining for TG2 in Indicaxanthin pre-treated OECs and then exposed to the fragment $A \beta(35-25)$ was found, when compared both with the controls and the fragment $A \beta(35-25)$ alone. In addition, the protein was prevalently localized in the cytosol. No specific staining of OECs was observed in control incubation in which the primary antibody was omitted.

\section{TG2 and its isoforms expression and effect of Indicaxanthin}

To assess and better clarify CLMS analysis performed on single cell relative to the different intracellular localization of TG2, the expression levels of the total TG2 and its isoforms (TG2-S and TG2-L) induced by the different treatment types, were evaluated through Western blot analysis on total cellular lysates. Immunoblots (Fig. 6A) and densitometric analysis (Fig. 6B) show an significant increase of total TG2 expression levels both in $A \beta(1-42)$ and $A \beta(25-35)$ exposed OECs, when compared with the controls. The effect was more evident in $A \beta(25-35)$-treated cells. Slight but no significant changes in total TG2 expression levels in cultures exposed to $A \beta(35-25)$ were found. Indicaxanthin pre-treatment did not induce significant modifications in total TG2 expression levels, when compared with the controls. When Indicaxanthin was added to OECs following exposed to $A \beta(1-42)$ or $A \beta(25-35)$ or $A \beta(35-25)$, a significant reduction of total TG2 expression levels was observed, when compared with the controls. The effect of the pre-treatment of the cells with Indicaxanthin was more evident in OECs exposed to $A \beta(25-$ 35). In Indicaxanthin pre-treated OECs and then exposed to the fragment $A \beta(35-25)$, a significant reduction of total TG2 expression levels was relieved, when compared with $A \beta(35-25)$, Indicaxanthin alone treated cells and with the controls.

To better elucidate the effect of OEC exposure to $A \beta(1-42)$ or $A \beta(25-35)$ or $A \beta(35-25)$ both in the absence and in the presence of Indicaxanthin on the role played by TG2, the expression levels of its isoforms were detected. Figure 7 reports the immunoblots (Fig. 7A) and densitometric analysis (Fig. 7B, C) performed on all experimental conditions. On the basis of the treatment type, different expression patterns of the isoforms were found. In controls (PBS and DMSO) both TG2 isoforms were expressed at very low levels, even if TG2-S levels were higher than TG2-L. $A \beta(1-42)$ treatment induced a significant increase of both isoform expression levels, when compared with the controls. The exposure of OECs to $A \beta(25-35)$ caused a significant increase of TG2-S and TG2-L, even if TG2-S levels were higher than TG2$L$ ones, when compared with $A \beta(1-42)$ exposed cells and with the controls. No significant change in TG2$L$ and TG2-S expression levels in cultures exposed to $A \beta(35-25)$ was found. When OECs were exposed to $100 \mu \mathrm{M}$ of Indicaxanthin, a significant increase of the both isoforms was found, when compared with the controls. The pre-treatment of the cells with Indicaxanthin and $A \beta(1-42)$ exposure induced a significant increase of TG2-L, when compared with TG2-S and with the controls. In contrast, Indicaxanthin pretreatment in $A \beta(25-35)$ exposed cells caused a significant enhancement of TG2-S expression levels, when compared with TG2-L ones. Furthermore, no significant changes in TG2-L expression levels in $A \beta(35-25)$ exposed OECs were observed. Surprisingly, Indicaxanthin pre-treatment caused a significant increase of the TG2-S expression levels, when compared with $A \beta(35-25)$, Indicaxanthin alone treated 
cells and with the controls. Densitometric analysis performed for each experimental conditions, after normalization with $\beta$-tubulin, confirmed all the results. These data highlighted that $A \beta$ treatment both in the absence and in the presence of Indicaxanthin differently modulates TG2 isoforms acting or on apoptotic pathway activation or on the cell self-renewal ability.

\section{Caspase-3 cleavage immunolabeling}

To verify the TG2-mediated apoptotic pathway in OECs exposed to $A \beta(1-42)$ or $A \beta(25-35)$, we evaluated the caspase-3 cleavage through immunocytochemical techniques. Figure 8 highlights caspase-3-positive OECs exposed to different conditions. In controls (PBS and DMSO) the positivity of cells for caspase-3 was almost absent. When the cells were exposed to $A \beta(1-42)$ or $A \beta(25-35)$, a strong activation of positive cells for caspase-3 was found, which appeared mainly localized in the cytoplasm. The effect was particularly evident in $A \beta(25-35)$, that is highly toxic for the cells. In $A \beta(35-25)$-treated cells a light positivity for caspase-3, when compared with the controls, was found. The treatment of OECs with $100 \mu \mathrm{M}$ of Indicaxanthin did not produce any positivity for caspase-3, when compared with the controls. In Indicaxanthin pre-treated cells and subsequently exposed to $A \beta(1-42)$ or $A \beta(25-35)$ a decrease for caspase-3-positive cells, which appeared at similar expression levels of the controls, was observed. A light increase of positive OECs was found in Indicaxanthin pre-treated cells and then exposed to the fragment $A \beta(35-25)$, when compared with Indicaxanthin alone and with the controls. No specific staining of OECs was observed in control incubation in which the primary antibody was omitted. These findings revealed the role played by TG2 in the control of apoptotic pathway activation both in A $\beta$ exposed OECs and Indicaxanthin pre-treated ones.

\section{Cyclin $D_{1}$ expression levels and Nestin immunolabeling}

To assess the role played of TG2 in the cellular repair induced by Indicaxanthin on OEC exposed to $A \beta$, cyclin $D_{1}$ expression levels and the cell positivity for Nestin were examined. Western Blot and densitometric analysis for cyclin $D_{1}$ performed on total cellular lysates from $A \beta(1-42), A \beta(25-35)$ and $A \beta(35-25)$ exposed OECs both in the absence and in the presence of $100 \mu \mathrm{M}$ Indicaxanthin were reported in the Fig. 9A,B. A significant decrease in cyclin $D_{1}$ expression levels in $A \beta(1-42)$ exposed cells, when compared with controls, were found. The toxic fragment $A \beta(25-35)$ induced very strong reduction of cyclin $D_{1}$ expression levels respect to the full native $A \beta(1-42)$ peptide and the controls. In contrast, the exposure of OECs to no-toxic fragment $A \beta(35-25)$ did not cause significant modifications in cyclin $D_{1}$ expression levels, when compared with the controls. The pre-treatment of the cells with Indicaxanthin alone did not induced any significant change of protein expression levels, when compared with the controls. When it was added to OECs following exposed to $A \beta(1-42)$, a significant increase of cyclin $D_{1}$ expression levels, when compared with $A \beta(1-42)$ alone was observed, and protein levels appeared similar to those found in the controls and in Indicaxanthin alone. A significant increase of cyclin $D_{1}$ expression levels in $A \beta(25-35)$ treated with Indicaxanthin was highlighted, when compared with $A \beta(25-$ 35) alone (Fig. 9A, B), even if its levels were at lower than Indicaxanthin plus $A \beta(1-42)$, Indicaxanthin alone and controls. 
Figure 10 reports the positivity for Nestin in OECs exposed to Indicaxanthin in the absence and in the presence of $A \beta(1-42), A \beta(25-35), A \beta(35-25)$. A significant reduction in the number of positive cells for Nestin in $A \beta(1-42)$ and $A \beta(25-35)$ exposed was found, when compared with the controls. $A \beta(35-25)$ exposed cells showed a light increase for Nestin positive OECs, when compared with the controls. The pre-treatment of cultures with $100 \mu \mathrm{M}$ of Indicaxanthin for $24 \mathrm{~h}$ did not induce changes for Nestin positive cells, which appeared similar to the levels observed in the controls. When OECs were pre-treated with $100 \mu \mathrm{M}$ of Indicaxanthin and subsequently were exposed to $A \beta(1-42)$ or $A \beta(25-35)$, a strong increase of positive cells for Nestin was found, when compared with the controls. A low of Nestin positivity in Indicaxanthin pre-treated cells and then exposed to A $3(35-35)$ was shown. No specific staining of OECs was observed in control incubation in which the primary antibody to was omitted.

This set of experiments demonstrated that Indicaxanthin pre-treatment stimulated TG2 repair activity in OEC exposed to $A \beta$, activating also the stem self-renewal through the increase of cyclin $D_{1}$ expression levels and the cell positivity for Nestin.

\section{Discussion}

The aim of this study was to assess TG2 and its isoform expression levels in both OECs exposed to full native peptide of $A \beta(1-42)$ and its toxic fragment $A \beta(25-35)$. Epidemiological evidences report that the effects of Mediterranean Diet “MeDi” could be an alternative prophylaxis treatment for AD [32]. In particular, it has been identified in Sicily an increased frequency of centenarians, a reduced occurrence of mental and cognitive diseases, when compared with other Italian or European regions [19, 20]. One of the factors that could contribute to this phenomenon is the large availability of some rare specific nutrients, largely present in some area of Sicily, as well as Indicaxanthin from Opuntia ficus-indica fruit. Therefore, for the first time, we tested the effect of Indicaxanthin pre-treatment on OECs exposed to A $\beta$. Since cytoskeleton plays an important role in the pathogenesis of neurodegenerative diseases, including $A D$ [33], particular attention was focused on the effect of Indicaxanthin on some cytoskeletal proteins, such as Vimentin, GFAP, that have an important role in astrogliosis, a typical sign of AD [34]. Furthermore, the expression levels of cyclin $D_{1}$, which is induced in stem cell reprogramming and is co-expressed with Nestin, marker of neural stem cells [26], were assessed. In addition, the effect of $A \beta(1-42), A \beta(25-35)$ and $A \beta(35-25)$ in the absence and in the presence of Indicaxanthin was tested on cellular viability and on the activation of apoptotic pathway. Intracellular total ROS and $\mathrm{O}_{2}{ }^{-}$production was also evaluated. The experiments were performed on OECs because they represent a glial population of olfactory system that is also involved in AD [12]. It is note that olfactory dysfunction, as well as hyposmia and olfactory memory loss, represent the early symptoms of $\operatorname{AD}[18,35,36]$. Furthermore, it has been demonstrated that anterior olfactory nucleus (AON) projects to hippocampus [37] and that it is the earliest site involved in $A D$, associated with cell loss, the neurofibrillary tangles and senile plaques [12].

Previous our researches demonstrated that TG2 is overexpressed in OECs exposed to $A \beta(1-42)$ and its toxic fragment $A \beta(25-35)$ and that the treatment with some Growth Factors (GFs) was able to restore its levels to control values [18]. In particular, TG2, a calcium-dependent protein with transamidanting activity, 
is involved in $A D$, inducing the formation of insoluble amyloid aggregates that can alter the properties of several proteins [2]. TG2 activity is down-regulated in response to oxidative stress [29, 30] and this effect could be related to the increase of the intracellular $\mathrm{Ca}^{2+}$ levels due to $A \beta$ toxicity [18]. In fact, the accumulation of extracellular protein aggregates prevalently constituted by polymeric $A \beta$, caused by the aberrant transamidanting activity of TG2, are also related to a dysregulation of autophagy process [38]. These conditions contribute to oxidative stress and neural cell death, in which TG2 plays a key role [30]. It has been reported that hippocampal neurons are more responsive to Indicaxanthin [39]. In particular, it has an important role in several metabolic functions both in vitro and in vivo, reducing inflammation and enhancing immune response $[22,23,40]$.

In this study, for the first time, we highlight that the OEC exposure to $A \beta(1-42)$, its fragments $A \beta(25-35)$ and $A \beta(35-25)$ induces a different expression pattern of TG2-L and TG2-S, demonstrating the opposite role played by TG2. Furthermore, we show the protective effect exerted by Indicaxanthin pre-treatment on total TG2 and its isoforms expression levels. In particular, we found that in $A \beta(1-42)$ treated cells the two isoforms appeared at same expression levels, whereas in $A \beta(25-35)$ exposed ones TG2-S was at higher levels than TG2-L, when compared with $A \beta(1-42)$ exposed cells and with the controls. In OECs exposed to $A \beta(35-25)$, a light modification between TG2-L and TG2-S expression levels was observed. The pretreatment with Indicaxanthin was able to counteract the oxidative damage following the exposure of the cells to full native peptide of $A \beta(1-42)$ and its toxic fragment $A \beta(25-35)$, restoring the expression levels of total TG2 to control values. Furthermore, CLSM analysis performed on single cell showed that TG2 in OECs pre-treated with Indicaxanthin alone was localized in the cytosol. In contrast, when cells were pretreated with Indicaxanthin and then exposed to $A \beta(1-42)$, the protein appeared prevalently localized into the nuclear compartment. In the cells pre-treated with Indicaxanthin and then stressed with $A \beta(25-35)$, TG2 was localized both in the cytosol and in the nucleus. Western blot analysis showed a significant increase in TG2-L in Indicaxanthin alone treated cells and in those then exposed cells to $A \beta(1-42)$. This effect might be correlated to the role played by TG2 when it is localized into the nuclear compartment, in which it acts on the control of cell proliferation, regulating gene expression, cell survival and differentiation, exerting an anti-apoptotic function [10, 18, 41]. In OECs treated with Indicaxanthin alone and in those subsequently exposed to $A \beta(25-35)$, an increase of TG2-S expression levels was observed. The effect appeared more evident in the cells pre-treated with Indicaxanthin. TG2-S, even if reduced respect to that found in $A \beta(25-35)$ treated cells, exerts transamidanting activity and acts as apoptotic factor $[6,18]$. Surprisingly, Indicaxanthin pre-treatment in $A \beta(35-25)$ exposed cells, induced a significant increase of TG2-S expression levels, when compared with $A \beta(35-25)$ alone and controls. This finding might be due to the strong protective effect of Indicaxanthin, since we hypothesize that $A \beta(35-25)$ fragment, even if it was reported that is not toxic [25], was able to induce a low toxicity in OECs, as relieved by a very significant increase of TG2-S expression levels when compared with exposed cells to $A \beta(35-25)$ alone. Thus, we suppose that this effect may be due to the protective role played by TG2, which stimulates its pro-apoptotic activity, in order to remove damaged cells and to induce cellular repair. We also found that Indicaxanthin counteracted the oxidative stress induced by $A \beta$, as relieved by the reduction of total ROS and $\mathrm{O}_{2}{ }^{-}$production, that appeared similar to those observed in the controls. Thus, 
Indicaxanthin pre-treatment, for its antioxidant properties, was able to reduce the A $\beta$-toxicity, oxidative stress-dependent and mitochondrial damage. In addition, Indicaxanthin, with its anti-inflammatory proprieties, decreased GFAP and Vimentin expression levels, that were enhanced in A $\beta$ exposed OECs. These results highlighted that Indicaxanthin exerted a protective effect on reactive astrogliosis induced by $A \beta$ responsive of cytoskeleton modifications. Furthermore, to clarify the protective role played by TG2 in the absence and in the presence of Indicaxanthin, the levels of Nestin, marker of neural stem selfrenewal, co-expressed with cyclin $D_{1}$, marker of cellular proliferation [26], were assessed. These results show an increase of positive cells for Nestin and cyclin $D_{1}$ expression levels, demonstrating that Indicaxanthin pre-treatment, stimulating the activity played by nuclear TG2 on stem self-renewal OEC reprogramming, that stimulates cell proliferation repairing the damage induced by $A \beta$. We also observed that Indicaxanthin counteracted the TG2-aberrant cross-linking activity induced by A -exposure on the cells, evaluating caspase- 3 cleavage, that appeared reduced following to its treatment. This effect might be correlated to the function that TG2 exerts on the apoptotic pathway, as revealed by the increase of TG2-S expression levels observed in our experimental conditions, when cells were treated with $A \beta(1-42)$ and $A \beta(25-35)$ in the absence of Indicaxathin. In contrast, total TG2 did not show its opposite role on the basis of cellular localization and did not evidence the effect of $A \beta$ both in the absence and in the presence of Indicaxanthin.

Taken together, our findings demonstrate that $A \beta$ stress is responsible of TG2 up-regulation [18] and its structural modifications in two distinct conformational states with different functions [10]. In fact, when the levels of $\mathrm{Ca}^{2+}$ are low and those of guanosin triphosphate (GTP) or guanosin diphosphate (GDP) are high, TG2-L acts as a GTPase, is involved in signaling pathway, is inactive and is present in "closed" conformation, promoting cell growth and survival (Fig. 11A). A $\beta$ exposure of OECs, increasing intracellular $\mathrm{Ca}^{2+}$ and decreasing GTP or GDP levels, might cause a change of TG2-L from "closed" to "open" conformation, catalytically active. In addition, $A \beta$ treatment induced an increase of the levels of TG2-S, an alternative splice variant of TG2 lacking of the portion of the carboxyl terminal essential for the maintenance of the protein in the "closed" conformation, that is responsible of apoptotic activation and cell death. The effect is more evident when the cells were exposed to the major toxic $A \beta(25-35)$ fragment, that strongly enhanced intracellular $\mathrm{Ca}^{2+}$ levels (Fig. 11B). Indicaxanthin pre-treatment prevented total TG2 over-expression induced by the $O E C$ exposure to full native peptide $A \beta(1-42)$ and $A \beta(25-35)$ fragment, probably binding to $\mathrm{Ca}^{2+}[40]$. The significant increase of TG2-L isoform expression levels induced by $A \beta(1-42)$, accompanied by the decrease of TG2-S ones, is related to the role that the protein plays into the nucleus, in which it might stimulate OEC self-renewal and the reparative effect against $A \beta$ toxicity (Fig. 11C). Furthermore, in $A \beta(25-35)$ exposed OECs Indicaxanthin is able to significantly decrease TG2-S isoform expression levels enhancing at the same time those of TG2-L. The different expression pattern of TG2 isoforms in $A \beta(25-35)$ exposed cells in the presence of Indicaxanthin might be due to the major toxicity of the fragment that induces a major enhancement of $\mathrm{Ca}^{2+}$. Thus, in this conditions, the protein was able to stimulate both apoptosis and self-renewal (Fig. 11D).

\section{Conclusions}


Our findings clearly highlighted that $A \beta$ exposure on OECs induced an increase of TG2 and a different expression pattern of its isoforms. Furthermore, the pre-treatment of the cells with Indicaxanthin was able to decrease total TG2 expression levels, inducing a different pattern of TG2 isoforms that might be due to change of TG2 state conformation. It also reduced total ROS and $\mathrm{O}_{2}{ }^{-}$production and the expression levels of GFAP and Vimentin, inhibiting glial reactivity and the activation of apoptotic pathway induced by $A \beta$. Furthermore, it leads to an increase of Nestin and cyclin $D_{1}$ expression levels, stimulating OECs selfrenewal and TG2 reparative role. In addition, our data suggest that in OECs exposed to $A \beta$ both in the absence and in the presence of Indicaxanthin might differently induce the transition of TG2 between "closed" and "open" conformation providing a new mechanism involved in the signal pathways activated by the protein in $A \beta$ injury. Therefore, further studies need to better clarify whether Indicaxanthin plays an important role for adopting the TG2 open conformation, that has a key role in self-renewal ability of OECs, which are cells capable of expressing and releasing neurotrophic receptors, and might represent a promising tool for neural regeneration in AD.

\section{Abbreviations}

AD: Alzhèimer Disease; Aß: Amyloid Beta; TG2: Tissue transglutaminase; TG2-L: Tissue transglutaminase Long; TG2-S: Tissue transglutaminase Short; OECs: Olfactory Ensheathing Cells; ROS: Reactive Oxygen Species; $\mathrm{O}_{2}{ }^{-}$:Superoxide anion; GFAP: Glial Fibrillary Acidic Protein; DMEM: Dulbecco Modified Eagles Medium; FBS: Foetal Bovine Serum.

\section{Declarations}

\section{Ethics approval and consent to participate}

Experiments were carried out in compliance with the Italian law on animal care no. 116/1992 and in accordance with the European Community Council Directive (86/609/EEC) and were approved by the Ethical Committee at the University of Catania (Italy).

\section{Consent for publication}

All authors have given their consent for publication.

\section{Availability of data and materials}

The datasets used and analysed during the current study are available from the corresponding author on reasonable request.

\section{Competing interests}

The Authors declare that they have no conflicts of interest.

\section{Funding}


The research was partially supported by grant from "Piano della Ricerca 2016-2018, Dotazione Ordinaria, Linea di intervento 2, n. 0003690", prof. A. Campisi and by grant from Chance Announcement DR n. 1393, 28/04/2017 prof. G. Raciti.

\section{Authors' contributions}

AC and RP: design of the study and writing of the first draft. GS and MS: acquisition and analysis of data. RG: statistical analysis. GR, RG, MAC, UC reviewed the manuscript for important intellectual content. AA, $L T, M A$ purified and synthesized indicaxanthin All authors read and approved the final manuscript.

\section{Acknowledgments}

The Authors would like to thank Dr. Julia Bisicchia for her useful technical help.

\section{References}

1. Kandimalla R, Reddy PH. Therapeutics of Neurotransmitters in Alzheimer's Disease. J Alzheimer's Dis. 2017;57:1049-69.

2. Lesort M, Tucholski J, Miller ML, Johnson GV. Tissue transglutaminase: a possible role in neurodegenerative diseases. Prog Neurobiol. 2000;61:439-63.

3. Hasegawa G, Suwa M, Ichikawa Y, Ohtsuka T, Kumagai S, Kikuchi M, Sato Y, Saito Y. A novel function of tissue-type transglutaminase: protein disulphide isomerase. Biochem J. 2003373:793-803.

4. Nakaoka H, Perez DM, Baek KJ, Das T, Husain A, Misono K, Im, MJ, Graham RM. Gh: a GTP-binding protein with transglutaminase activity and receptor signaling function. Science 1994; 264:1593-96.

5. Campisi A, Caccamo D, Raciti G, Cannavò G, Macaione V, Currò M, Macaione S, Vanella A, lentile R. Glutamate-induced increases in transglutaminase activity in primary cultures of astroglial cells. Brain Res. 2003;978:24-30.

6. Milakovic T, Tucholski J, McCoy E, Johnson GV. Intracellular localization and activity state of tissue transglutaminase differentially impacts cell death. J Biol Chem. 2004;279:8715-22.

7. Kuo TF, Tatsukawa H, Kojima S. New insights into the functions and localization of nuclear transglutaminase 2. FEBS J. 2011;278:4756-67.

8. Mishra S, Melino G, Murphy LJ. Transglutaminase 2 kinase activity facilitates protein kinase Ainduced phosphorylation of retinoblastoma protein. J Biol Chem. 2007;282:18108-15.

9. Citron BA, Suo Z, SantaCruz K, Davies PJ, Qin F, Festoff BW. Protein crosslinking, tissue transglutaminase, alternative splicing and neurodegeneration. Neurochem Int. 2002;40:69-78.

10. Singh G, Zhang J, Ma Y, Cerione RA, Antonyak MA. The different conformational states of tissue transglutaminase have opposing effects on cell viability. J Biol Chem. 2016;291:9119-32.

11. Antonyak MA, Jansen JM, Miller AM, Ly TK, Endo M, Cerione RA. Two isoforms of tissue transglutaminase mediate opposing cellular fates. Proc Natl Acad Sci. 2006;103:18609-14. 
12. Attems $\mathrm{J}$, Walker $\mathrm{L}$, Jellinger KA. Olfactory bulb involvement in neurodegenerative diseases. Acta Neuropathol. 2014;127:459-475.

13. Pellitteri R, Spatuzza M, Stanzani S, Zaccheo D. Biomarkers expression in rat olfactory ensheathing cells. Front Biosci. 2010;2:289-98.

14. Pellitteri R, Spatuzza M, Russo A, Zaccheo D, Stanzani S. Olfactory ensheathing cells represent an optimal substrate for hippocampal neurons: an in vitro study. Int J Dev Neurosci. 2009;27:453-458.

15. Castiglione F, Ferro M, Mavroudakis E, Pellitteri R, Bossolasco P, Zaccheo D, Morbidelli M, Silani V, Meli A, Moscatelli D, Cova L. NMR Metabolomics for Stem Cell type discrimination. Sci Rep. 2017;7:15808-20.

16. Pellitteri R, Cova L, Zaccheo D, Silani V. Bossolasco P. Phenotypic modulation and neuroprotective effects of olfactory ensheathing cells: a promising tool for cell therapy. Stem Cell Rev Rep. 2016;12:224-34.

17. Franssen EH, de Bree FM, Verhaagen J. Olfactory ensheathing glia: their contribution to primary olfactory nervous system regeneration and their regenerative potential following transplantation into the injured spinal cord. Brain Res Rev. 2007;56:236-58.

18. Pellitteri R, Bonfanti R, Spatuzza M, Cambria M T, Ferrara M, Raciti G, Campisi A. Effect of some growth factors on tissue transglutaminase overexpression induced by $\beta$-amyloid in olfactory ensheathing cells. Mol Neurobiol. 2017;54:6785-94.

19. Mecocci $P$, Tinarelli $C$, Schulz RJ, Polidori MC. Nutraceuticals in cognitive impairment and Alzhèimer's disease. Front Pharmacol. 2014;5:147-58.

20. Tremocoldi MA, Rosalen PL, Franchin M, Massarioli AP, Denny C, Daiuto ÉR, Paschoal JAR, Melo PS, Alencar SM. Exploration of avocado by-products as natural sources of bioactive compounds. PLoS One. 2018;13:e0192577-89.

21. Naselli F, Tesoriere L, Caradonna F, Bellavia D, Attanzio A, Gentile C, Livrea MA. Anti-proliferative and pro-apoptotic activity of whole extract and isolated indicaxanthin from Opuntia ficus-indica associated with re-activation of the onco-suppressor p16(INK4a) gene in human colorectal carcinoma (Caco-2) cells. Biochem Biophys Res Commun. 2014;450:652-8.

22. Allegra $M$, De Cicco $P$, Ercolano $G$, Attanzio A, Busà R, Cirino G, Tesoriere L, Livrea MA, lanaro, A. Indicaxanthin from Opuntia ficus indica (L. Mill) impairs melanoma cell proliferation, invasiveness, and tumor progression. Phytomedicine. 2018;50:19-24.

23. Allegra M, Tutone M, Tesoriere L, Almerico AM, Culletta G, Livrea MA, Attanzio A. Indicaxanthin, a multi-target natural compound from Opuntia ficus-indica fruit: From its poly-pharmacological effects to biochemical mechanisms and molecular modelling studies. Eur J Med Chem. 2019;179:53-764.

24. Allegra M, Carletti F, Gambino, Tutone M, Attanzio A, Tesoriere L, Ferraro G, Sardo P, Almerico AM, Livrea MA. Indicaxanthin from Opuntia ficus-indica crosses the blood-brain barrier and modulates neuronal bioelectric activity in rat hippocampus at dietary-consistent amounts. J Agric Food Chem. 2015;63:7353-60. 
25. Choi J, Malakowsky CA, Talent JM, Conrad CC, Carroll CA, Weintraub ST, Gracy RW. Anti-apoptotic proteins are oxidized by Aß25-35 in Alzheimer's fibroblasts. Biochim Biophys Acta. 2003;1637:13541.

26. Chen CL, Wang LJ, Yan YT, Hsu HW, Su HL, Chang FP, Hsieh PCH, Hwang SM, Shen CN. Cyclin D1 acts as a barrier to pluripotent reprogramming by promoting neural progenitor fate commitment. FEBS Lett. 2014;588:4008-17.

27. Pellitteri R, Spatuzza M, Russo A, Stanzani S. Olfactory ensheathing cells exert a trophic effect on the hypothalamic neurons in vitro. Neurosci Lett. 2007;417:24-9.

28. Chuah MI, Au C. Cultures of ensheathing cells from neonatal rat olfactory bulbs. Brain Res. 1993;601:213-20.

29. Campisi A, Spatuzza M, Russo A, Raciti G, Vanella A, Stanzani S, Pellitteri R. Expression of tissue transglutaminase on primary olfactory ensheathing cells cultures exposed to stress conditions. Neurosci Res. 2012;72:289-95.

30. Campisi A, Caccamo D, Li Volti G, Currò M, G. Parisi G, R. Avola R, Vanella A, R. lentile R. Glutamate-evoked redox state alterations are involved in tissue transglutaminase upregulation in primary astrocyte cultures. FEBS Lett. 2004;578:80-4.

31. Grasso R, Dell'Albani P, Carbone C, Spatuzza M, Bonfanti R, Sposito G, Puglisi G, Musumeci F, Scordino A Campisi A. Synergic pro-apoptotic effects of Ferulic Acid and nanostructured lipid carrier in glioblastoma cells assessed through molecular and Delayed Luminescence studies. Sci Rep. 2020;10:4680-93.

32. Safouris A, Tsivgoulis G, Sergentanis TN, Psaltopoulou T. Mediterranean diet and risk of dementia. Curr Alzhèimer Res. 2015;12:335-349.

33. Rudrabhatla P. Regulation of neuronal cytoskeletal protein phosphorylation in neurodegenerative diseases. J Alzheimer's Dis. 2014;41:671-84.

34. Osborn LM, Kamphuis W, Wadman WJ, Hol EM. Astrogliosis: an integral player in the pathogenesis of Alzheimer's disease. Prog Neurobiol. 2016;144:121-41.

35. Djordjevic J, Jones-Gotman M, De Sousa K, Chertkow H. Olfaction in patients with mild cognitive impairment and Alzheimer's disease. Neurobiol Aging. 2008;29:693-706.

36. Vasavada MM, Martinez B, Wang J, Eslinger PJ, Gill DJ, Sun X, Karunanayaka P, Yang QX. Central olfactory dysfunction in Alzheimer's disease and mild cognitive impairment: a functional MRI study. J Alzheimer's Dis. 2017;59:359-68.

37. Aqrabawi AJ, Kim JC. Topographic organization of hippocampal inputs to the Anterior Olfactory Nucleus. Front Neuroanat. 2018;12:12-9.

38. Mputhia Z, Hone E, Tripathi T, Sargeant T, Martins R, Bharadwaj P. Autophagy modulation as a treatment of amyloid diseases. Molecules. 2019;24:3372-92.

39. Gambino G, Allegra M, Sardo P, Attanzio A, Tesoriere L, Livrea MA, Ferraro G, Carletti F. Brain distribution and modulation of neuronal excitability by indicaxanthin from Opuntia ficus indica administered at nutritionally-relevant amounts. Front Aging Neurosci. 2018;10:133-44. 
40. Tesoriere L, Attanzio A, Allegra M, Gentile C, Livrea MA. Phytochemical indicaxanthin suppresses 7ketocholesterol-induced THP-1 cell apoptosis by preventing cytosolic $\mathrm{Ca}\left({ }^{2+}\right)$ increase and oxidative stress. Brit J Nutr. 2013;110:230-40.

41. Tatsukawa H, Furutani Y, Hitomi K, Kojima S. Transglutaminase 2 has opposing roles in the regulation of cellular functions as well as cell growth and death. Cell Death Dis. 2016;7:e2244-e56.

\section{Figures}

A)

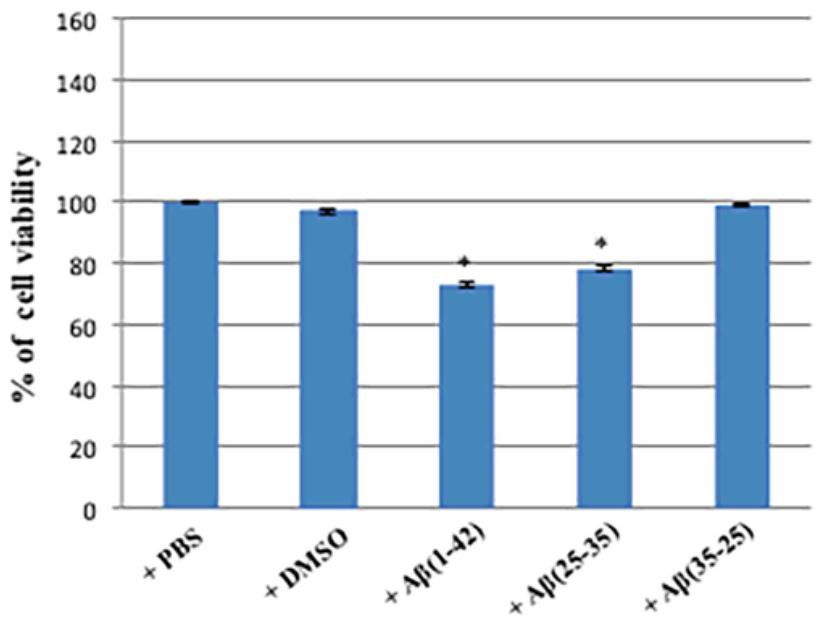

B)

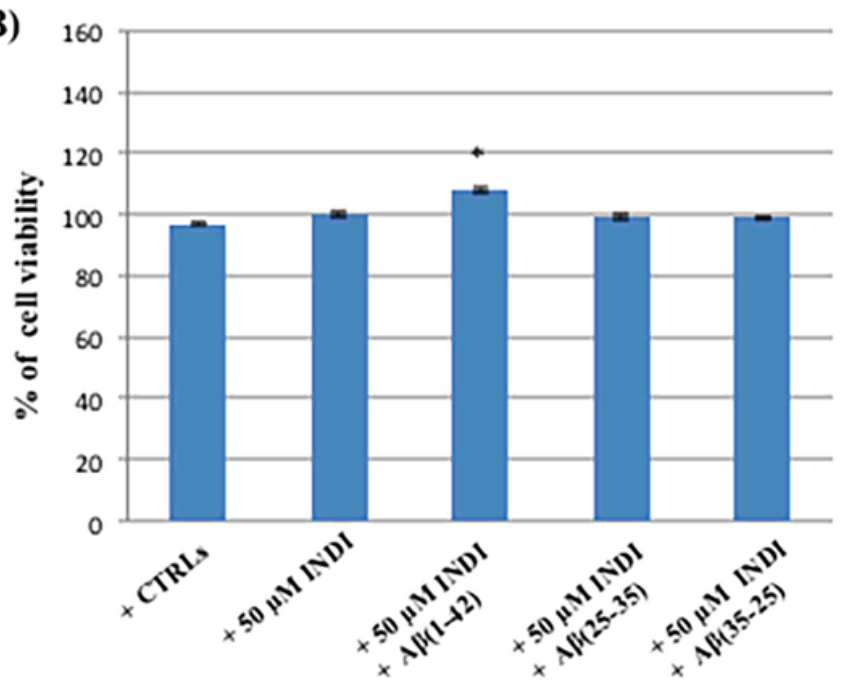

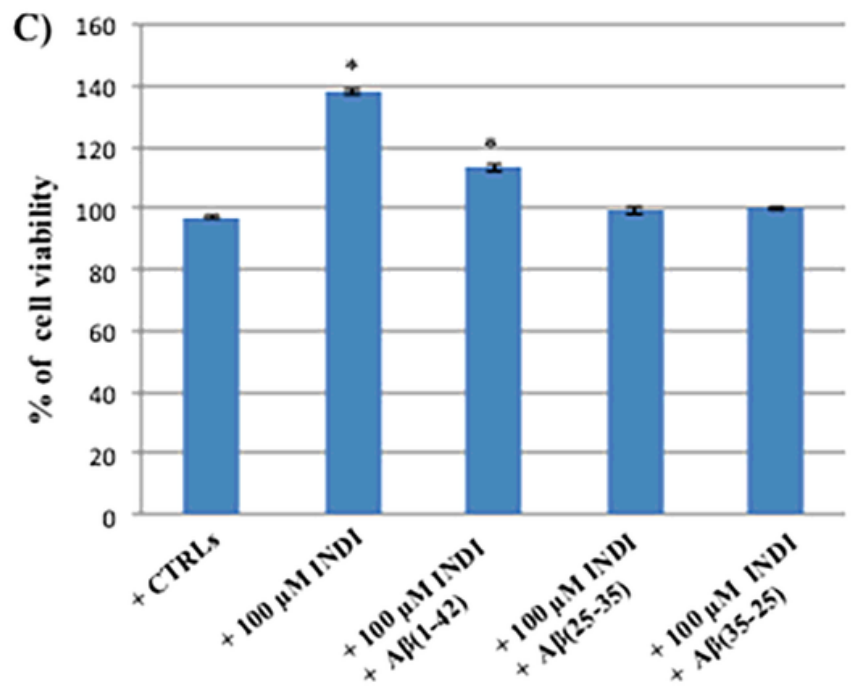

\section{Figure 1}

Percentage of cell viability in OECs performed through MTT test. (A) PBS and DMSO treated OECs, exposed to $10 \mu \mathrm{M} \mathrm{AB}(1-42)$ or $A \beta(25-35)$ or $A \beta(35-25)$ for $24 \mathrm{~h}$; (B) OECs pre-treated with $50 \mu \mathrm{M}$ Indicaxanthin (INDI) and exposed to $10 \mu \mathrm{M} A \beta(1-42)$ or $A \beta(25-35)$ or $A \beta(35-25)$ for $24 \mathrm{~h}$; (C) OECs pretreated with $100 \mu \mathrm{M} I N D I$ and exposed to $10 \mu \mathrm{M} A \beta(1-42)$ or $A \beta(25-35)$ or $A \beta(35-25)$ for $24 \mathrm{~h}$. Data were statistically analysed by using one-way analysis of variance (one-way ANOVA) followed by post hoc Holm-Sidak test, in order to calculate significant differences among groups. Data were reported 
represent the mean \pm S.D. of five separated experiments in triplicate. ${ }^{*} p<0.05$ significant differences vs controls.
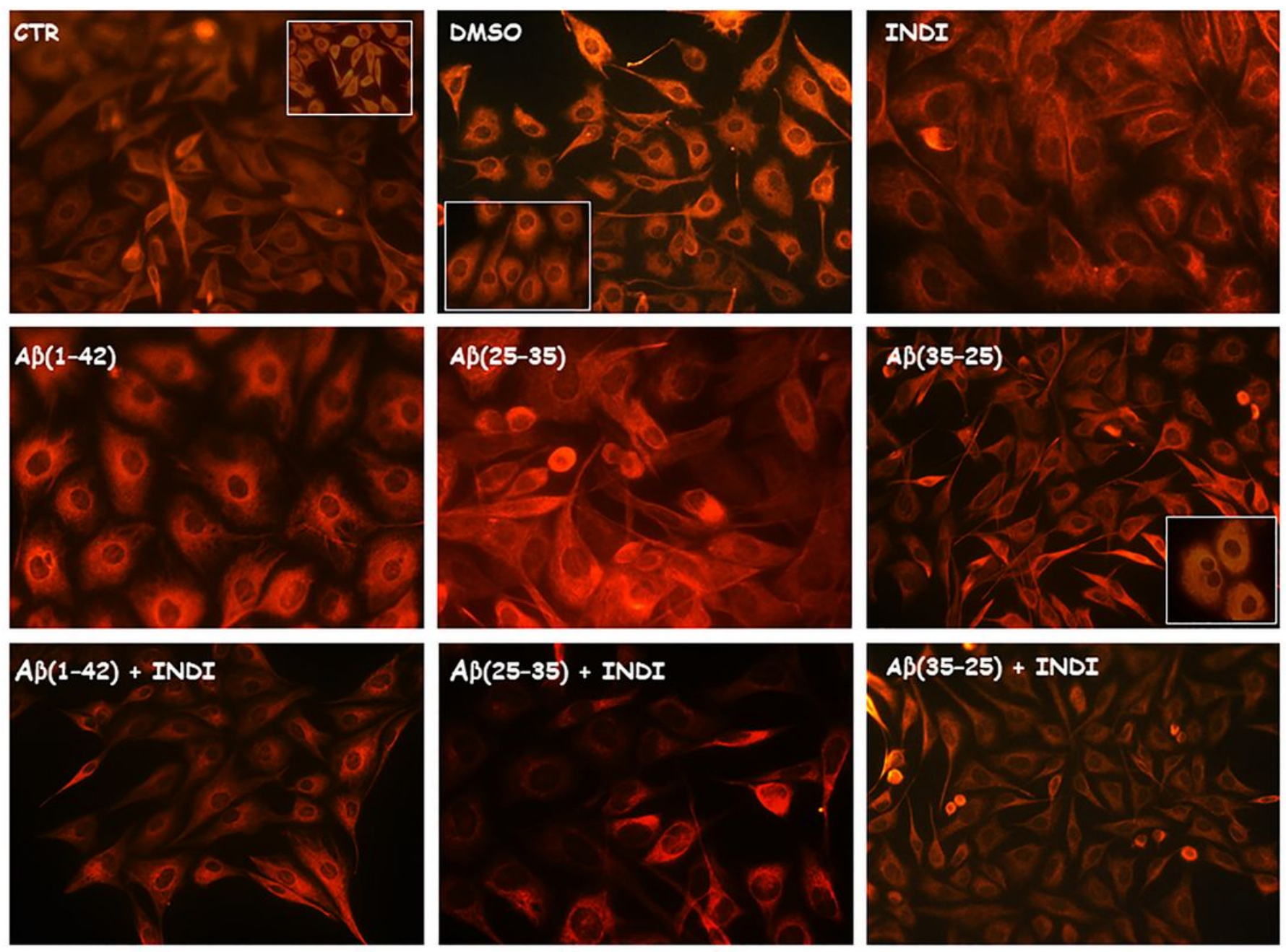

\section{Figure 2}

Immunocytochemistry for anti-Vimentin in OECs. Images show different conditions: control, DMSO, 100 $\mu \mathrm{M}$ Indicaxanthin (INDI), $10 \mu \mathrm{M} A \beta(1-42)$ or $A \beta(25-35)$ or $A \beta(35-25)$ both in the absence and in the presence of $100 \mu \mathrm{M}$ Indicaxanthin for $24 \mathrm{~h}$. Scale bar $20 \mu \mathrm{m}$. 

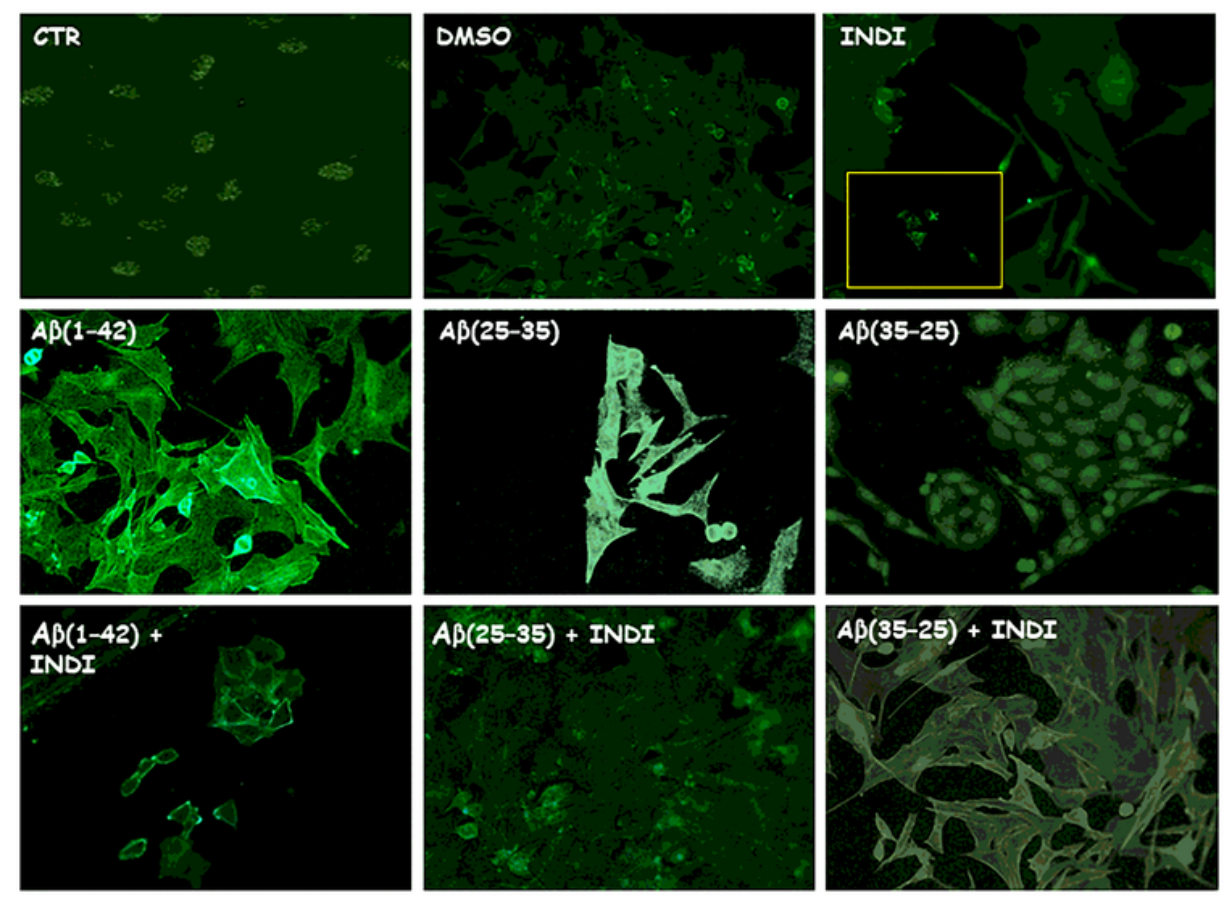

\section{Figure 3}

Immunocytochemistry for anti-GFAP in OECs. Images show different conditions: control, DMSO, $100 \mu \mathrm{M}$ Indicaxanthin (INDI), $10 \mu \mathrm{M} \mathrm{A \beta}(1-42)$ or $A \beta(25-35)$ or $A \beta(35-25)$ both in the absence and in the presence of $100 \mu \mathrm{M}$ INDI for $24 \mathrm{~h}$. Scale bar $20 \mu \mathrm{m}$. 

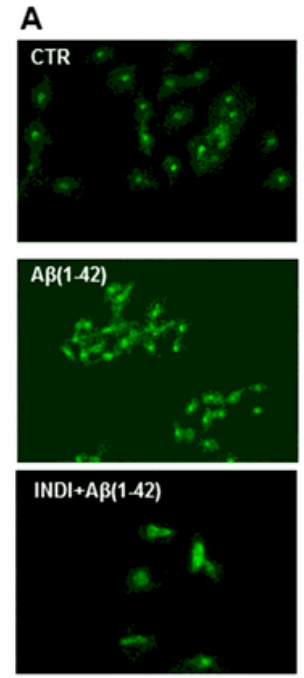

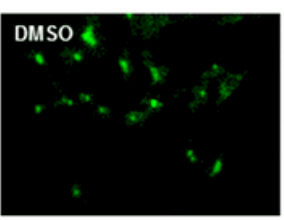

$A \beta(25.35)$

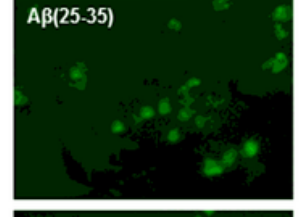

INDI+Aß(25-35)
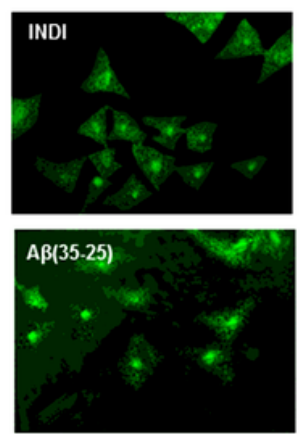

INDI+AB(35-25)

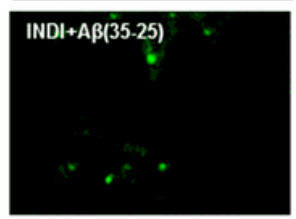

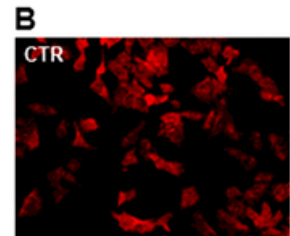

\section{$A \beta(1-42)$}

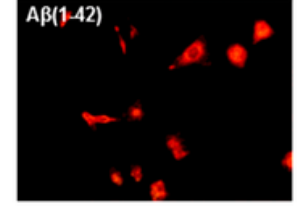

INDI+AB(1-42)

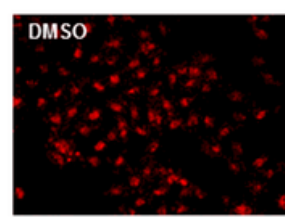

$A \beta(25-35)$

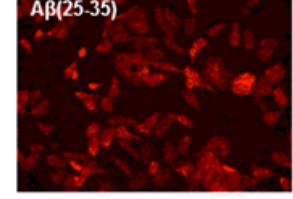

INDI+Aß(25-35)

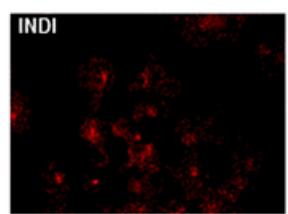

$\overline{A \beta}(35-25)$

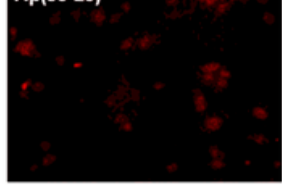

INDI+AB(35-25)

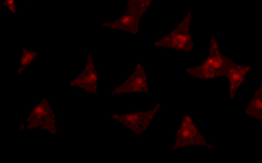

\section{$(1 \mathrm{DO}+\mathrm{AP}(35.25)$}
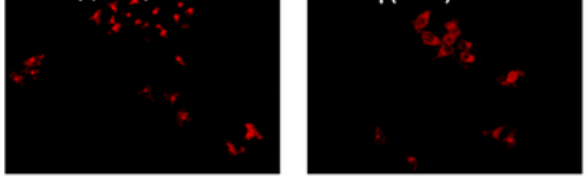

\section{Figure 4}

Staining of total intracellular ROS levels and 02-. Total intracellular ROS levels (green, Fig. 4A) and 02(red, Fig. 4B) generation in OECs in different conditions: control, DMSO, $100 \mu \mathrm{M}$ Indicaxanthin (INDI), 10 $\mu \mathrm{M} A \beta(1-42)$ or $A \beta(25-35)$ or $A \beta(35-25)$ both in the absence and in the presence of $100 \mu \mathrm{M}$ INDI for 24h. Scale bar $20 \mu \mathrm{m}$. 

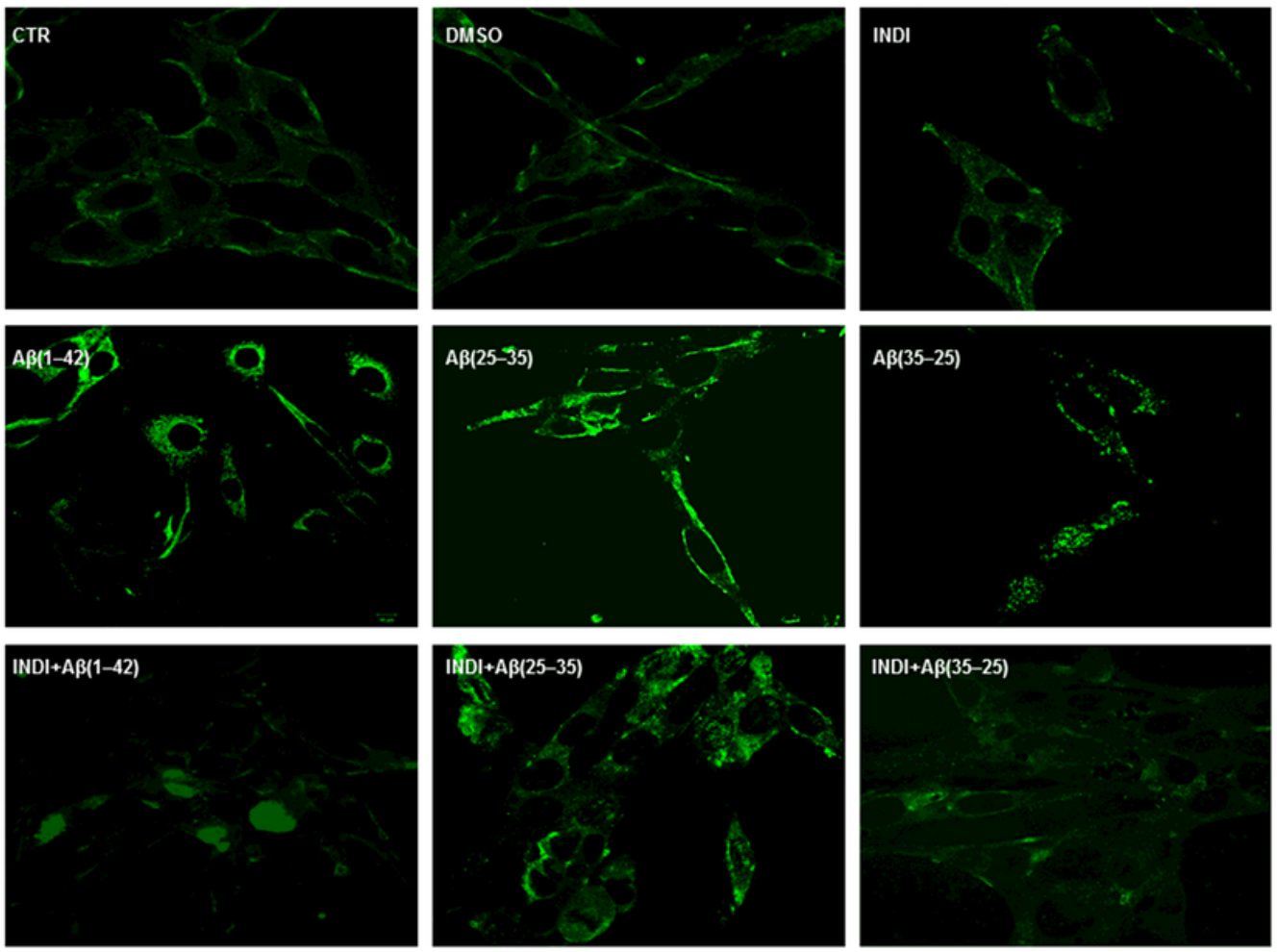

\section{Figure 5}

Confocal Laser Scanning Microscopy of labeling immunocytochemistry for anti-TG2 in OECs. Images show different conditions: control, DMSO, $100 \mu \mathrm{M}$ Indicaxanthin (INDI), $10 \mu \mathrm{M} A \beta(1-42)$ or $A \beta(25-35)$ or $A \beta(35-25)$ both in the absence and in the presence of $100 \mu \mathrm{M}$ INDI for $24 \mathrm{~h}$. Scale bar $20 \mu \mathrm{m}$. 
A)

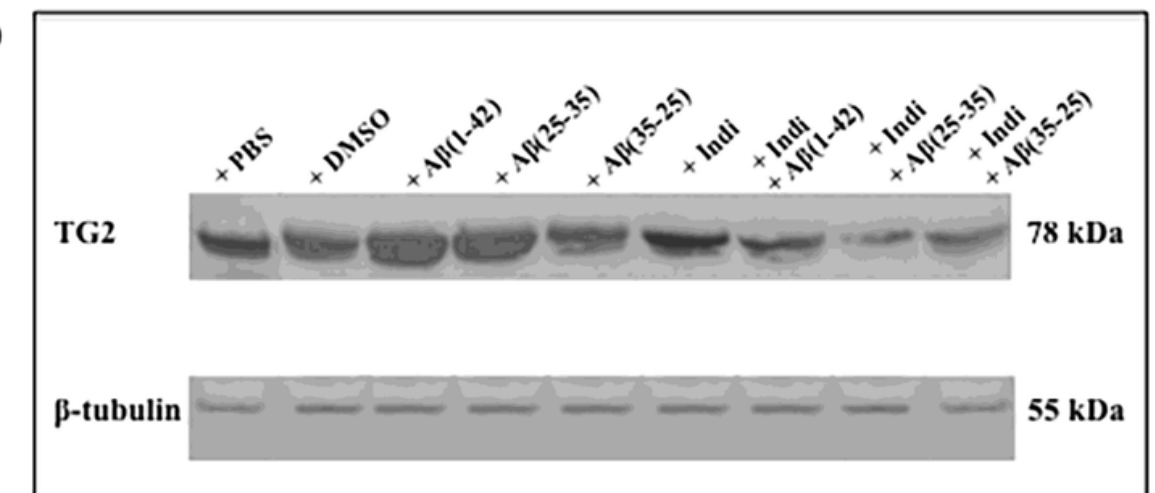

B)

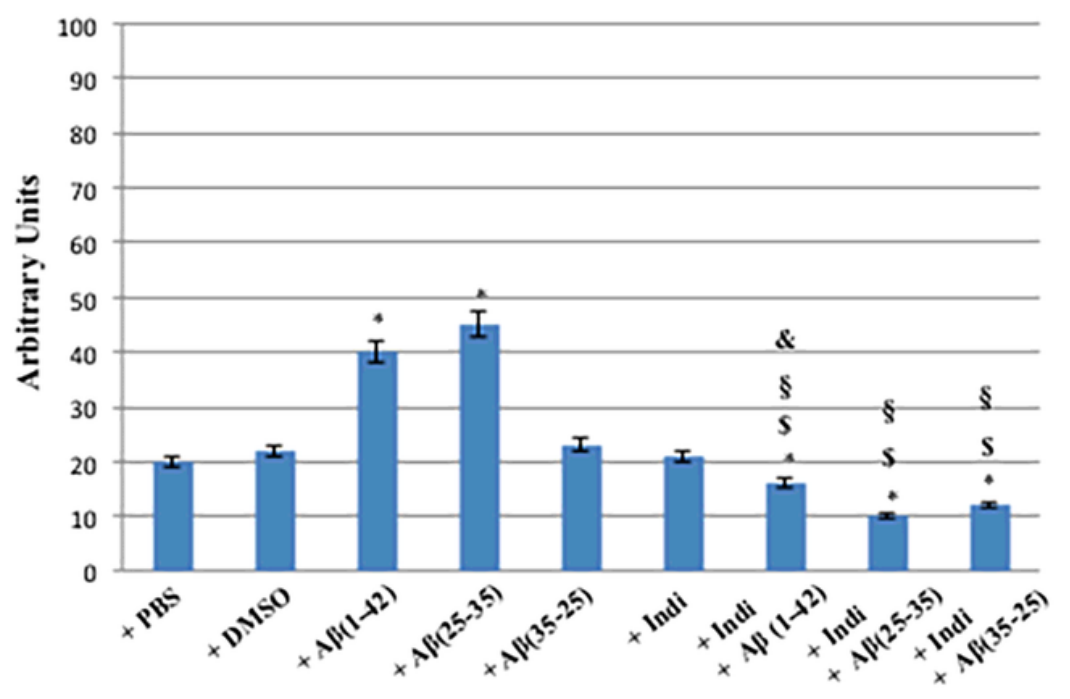

Figure 6

Western Blotting analysis. (A) Representative immunoblot for total TG2 expression levels in total cellular lysates from OECs in different conditions: control, DMSO, $100 \mu \mathrm{M}$ Indicaxanthin (INDI), $10 \mu \mathrm{M} \mathrm{A \beta (1-42)}$ or $A \beta(25-35)$ or $A \beta(35-25)$ both in the absence and in the presence of $100 \mu \mathrm{M}$ INDI for $24 \mathrm{~h}$. (B) Densitometric analysis of TG2 expression levels performed after normalization with $\beta$-tubulin. The results are expressed as the mean \pm S.D. of the values of five separate experiments performed in triplicate. ${ }^{*} p<$ 0.05 significant differences vs controls; $\$ p<0.05$ significant differences of $A \beta(1-42)+$ INDI or $A \beta(25-35)+$ INDI or $A \beta(35-25)+I N D I$ vs INDI; $\S p<0.05$ significant differences of $A \beta(1-42)+I N D I$ vs $A \beta(1-42), A \beta(25-$ $35)+$ INDI vs $A \beta(25-35)$ or $A \beta(35-25)+$ INDI vs $A \beta(35-25) ; \& p<0.05$ significant differences of $A \beta(1-42)+$ INDI vs $A \beta(25-35)+$ INDI or vs $A \beta(35-25)+$ INDI. 
A)
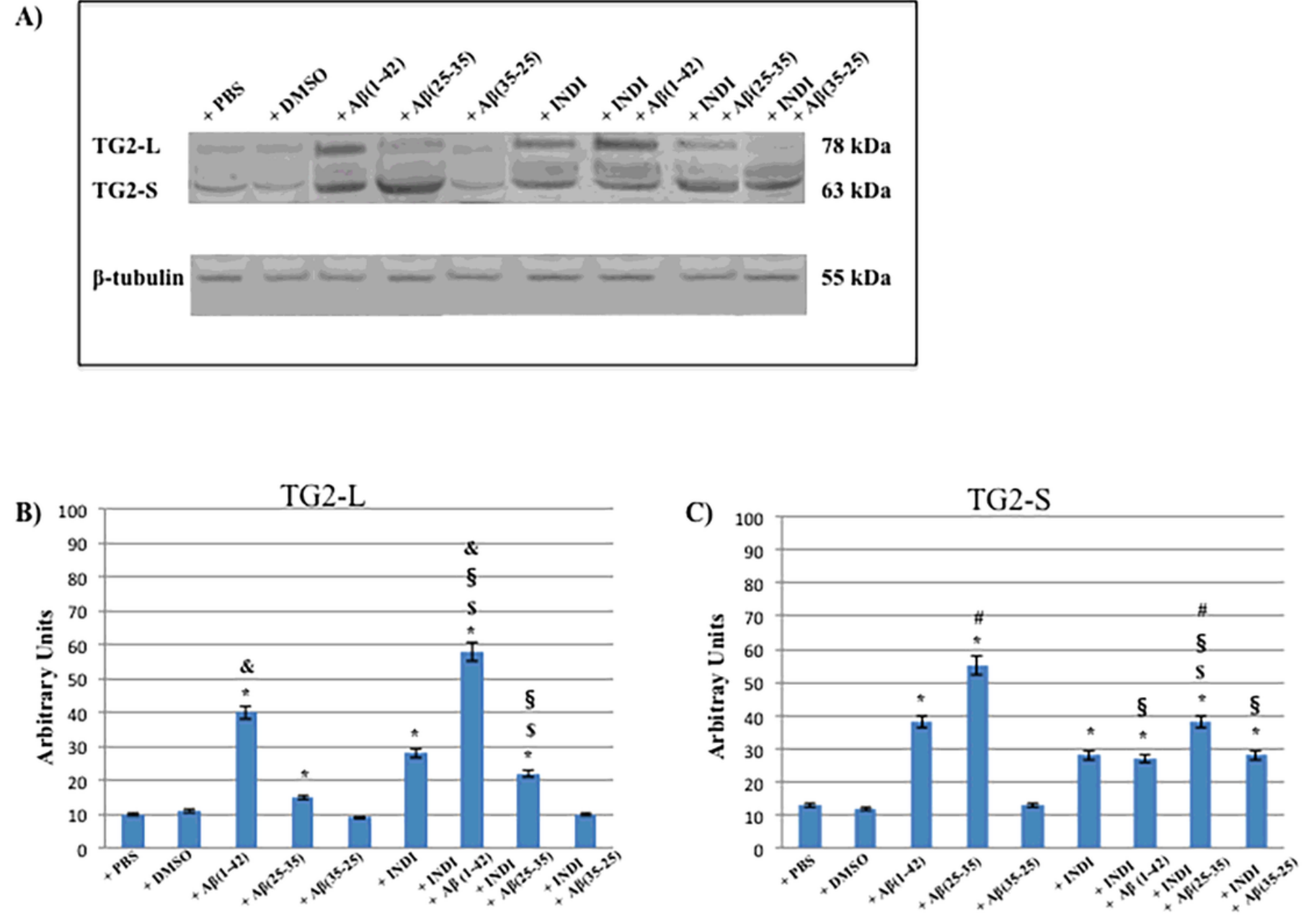

Figure 7

Western Blotting analysis. (A) Representative immunoblots through Western Blotting analysis for TG2 isoforms (TG2-L and TG2-S) expression levels in total cellular lysate from OECs in different conditions: control, DMSO, $100 \mu \mathrm{M}$ Indicaxanthin (INDI), $10 \mu \mathrm{M} A \beta(1-42)$ or $A \beta(25-35)$ or $A \beta(35-25)$ both in the absence and in the presence of $100 \mu \mathrm{M}$ INDI for 24h; (B) Densitometric analysis of TG2-L expression levels performed after normalization with $\beta$-Tubulin. (C) Densitometric analysis of TG2-S expression levels performed after normalization with $\beta$-tubulin. The results are expressed as the mean \pm S.D. of the values of five separate experiments performed in triplicate. ${ }^{*} p<0.05$ significant differences vs controls; $\$ p<0.05$ significant differences of $A \beta(1-42)+I N D I$ or $A \beta(25-35)+I N D I$ or $A \beta(35-25)+I N D I$ vs INDI; $\S p<$ 0.05 significant differences of $A \beta(1-42)+$ INDI vs $A \beta(1-42), A \beta(25-35)+$ INDI vs $A \beta(25-35)$ or $A \beta(35-25)+$ INDI vs $A \beta(35-25) ; \& p<0.05$ significant differences of $A \beta(1-42)$ vs $A \beta(25-35)$ or vs $A \beta(35-25)$ and of $A \beta(1-$ 42) vs $A \beta(25-35)+I N D I$ or vs $A \beta(35-25)+I N D I ; \# p<0.05$ significant differences of $A \beta(25-35)$ vs $A \beta(1-42)$ or vs $A \beta(35-25)$ and of $A \beta(25-35)+$ INDI vs $A \beta(1-42)+$ INDI or vs $A \beta(35-25)+$ INDI. 

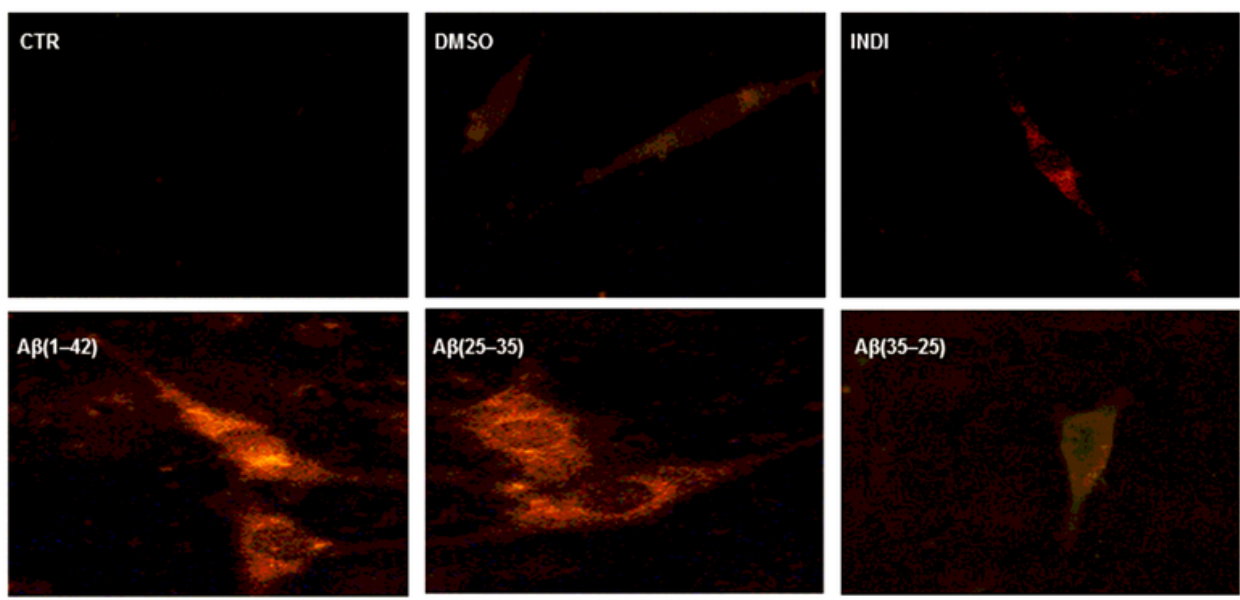

$A \beta(35-25)$

INDI+Aß|1-42)
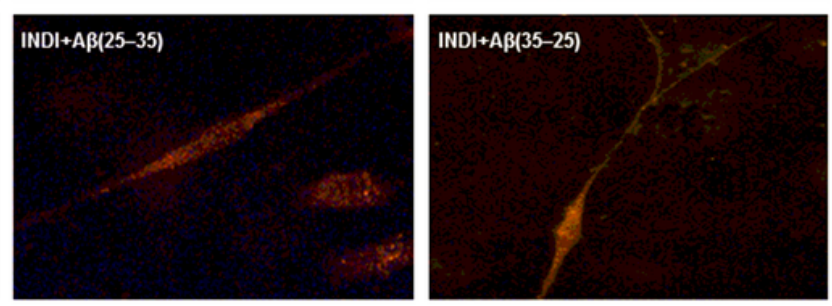

Figure 8

Immunocytochemistry for anti-Caspase-3 in OECs. Images show different conditions: control, DMSO, 100 $\mu \mathrm{M}$ Indicaxanthin (INDI), $10 \mu \mathrm{M} A \beta(1-42)$ or $A \beta(25-35)$ or $A \beta(35-25)$ both in the absence and in the presence of $100 \mu \mathrm{M}$ INDI for $24 \mathrm{~h}$. Scale bar $20 \mu \mathrm{m}$. 
A)

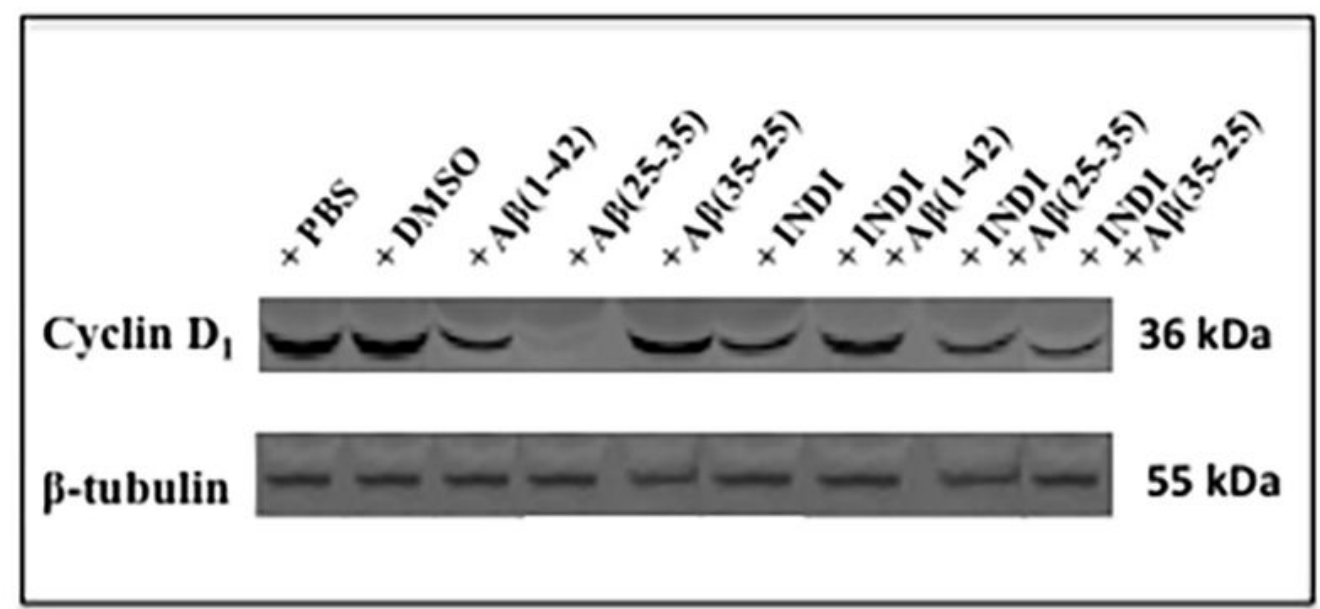

B)

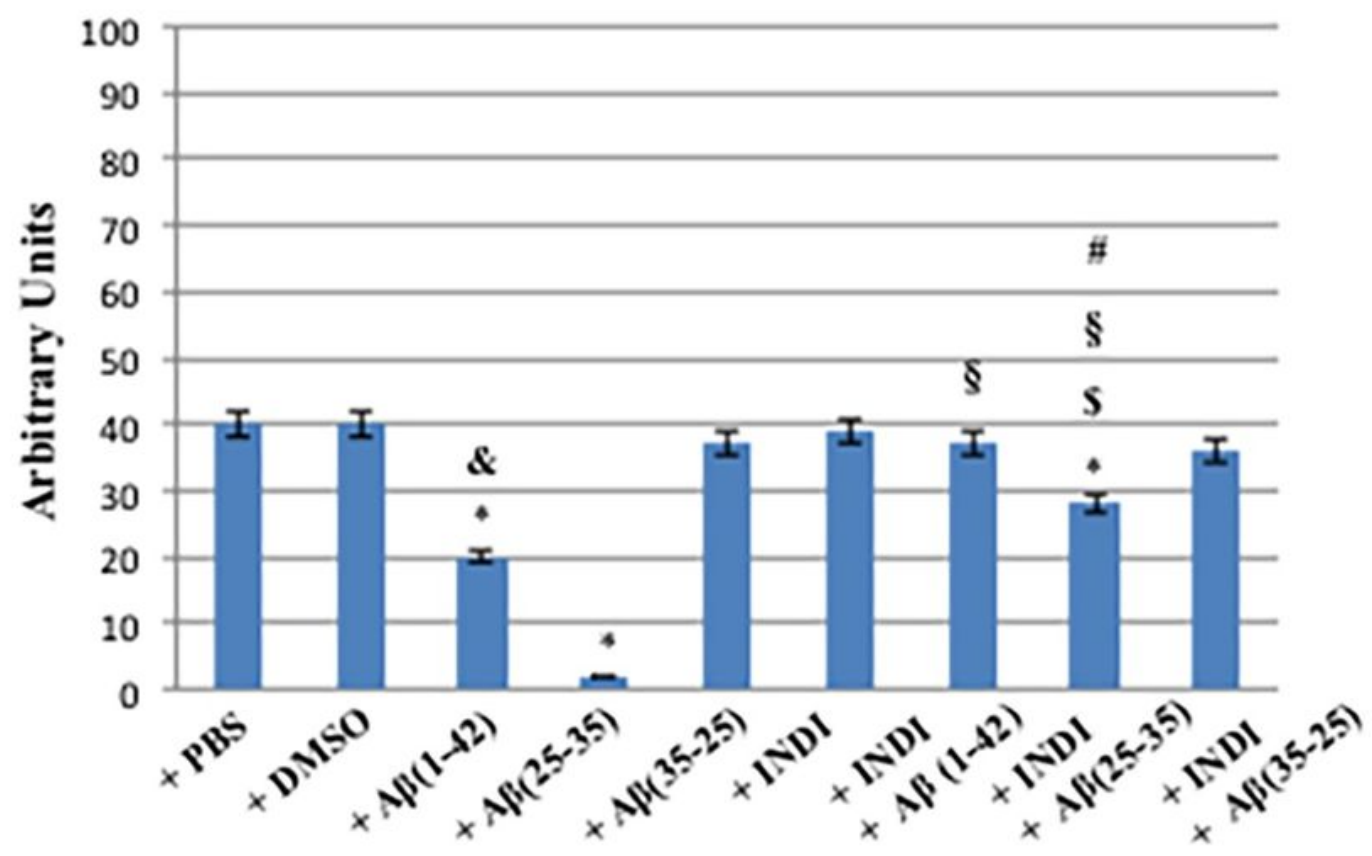

Figure 9

Western Blotting analysis. (A) Representative immunoblot through Western Blotting analysis for cyclin D1 expression levels in total cellular lysates from OECs in different conditions: control, DMSO, $100 \mu \mathrm{M}$ Indicaxanthin, $10 \mu \mathrm{M} A \beta(1-42)$ or $A \beta(25-35)$ or $A \beta(35-25)$ both in the absence and in the presence of $100 \mu \mathrm{M}$ Indicaxanthin for 24h. (B) Densitometric analysis of cyclin D1 expression levels performed after normalization with $\beta$-tubulin. The results are expressed as the mean \pm S.D. of the values of five separate 
experiments performed in triplicate. ${ }^{*} p<0.05$ significant differences vs controls. $\$ p<0.05$ significant differences of $A \beta(1-42)+I N D I$ or $A \beta(25-35)+I N D I$ or $A \beta(35-25)+$ INDI vs INDI; $\S p<0.05$ significant differences of $A \beta(1-42)+$ INDI vs $A \beta(1-42), A \beta(25-35)+$ INDI vs $A \beta(25-35)$ or $A \beta(35-25)+$ INDI vs $A \beta(35-$ $25) ; \& p<0.05$ significant differences of $A \beta(1-42)$ vs $A \beta(25-35)$ or vs $A \beta(35-25) ; \# p<0.05$ significant differences of $A \beta(25-35)+$ INDI vs $A \beta(1-42)+$ INDI or vs $A \beta(35-25)+$ INDI.
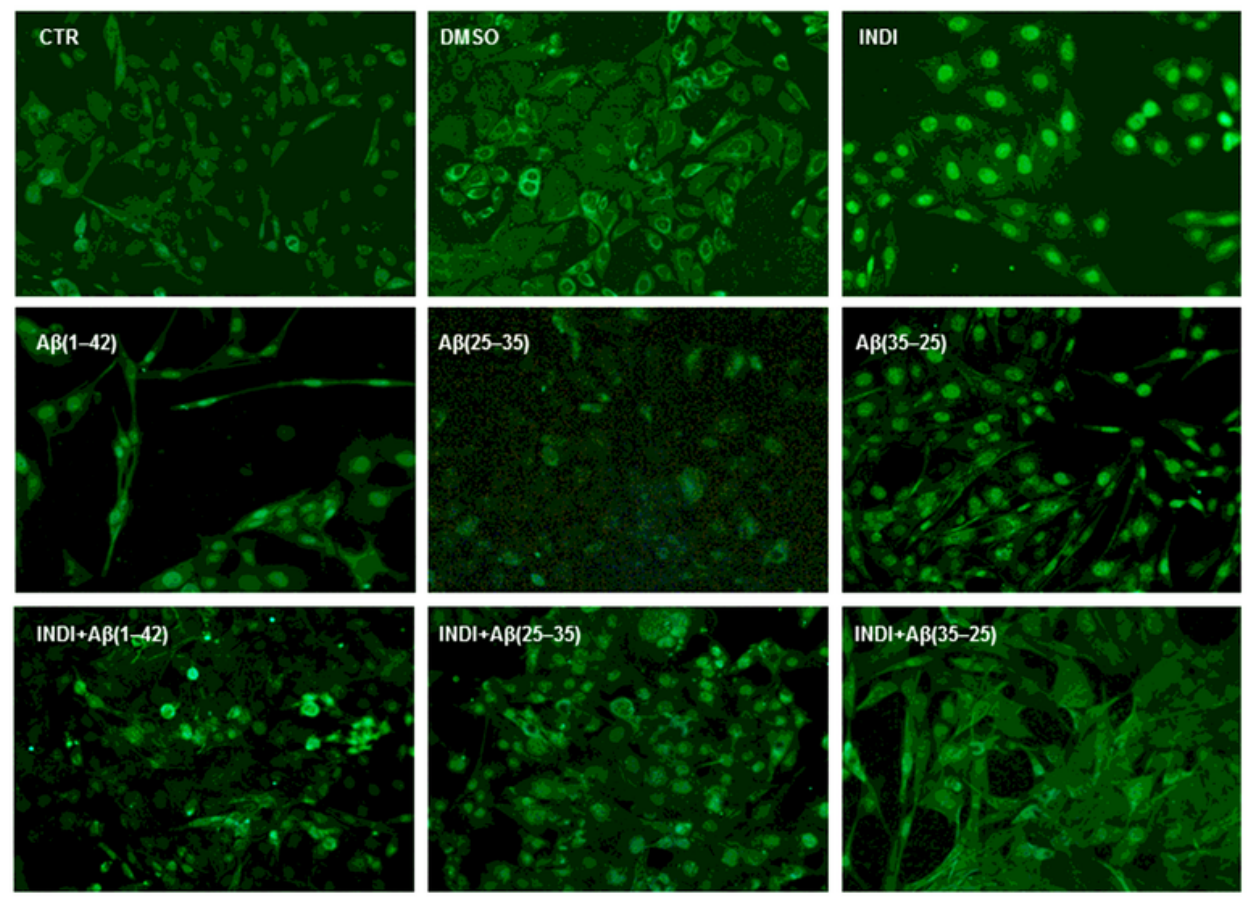

\section{Figure 10}

Immunocytochemistry for anti-Nestin in OECs. Images show different conditions: control, DMSO, $100 \mu \mathrm{M}$ Indicaxanthin (INDI), $10 \mu \mathrm{M} \mathrm{A \beta}(1-42)$ or $A \beta(25-35)$ or $A \beta(35-25)$ both in the absence and in the presence of $100 \mu \mathrm{M}$ INDI for $24 \mathrm{~h}$. Scale bar $20 \mu \mathrm{m}$. 

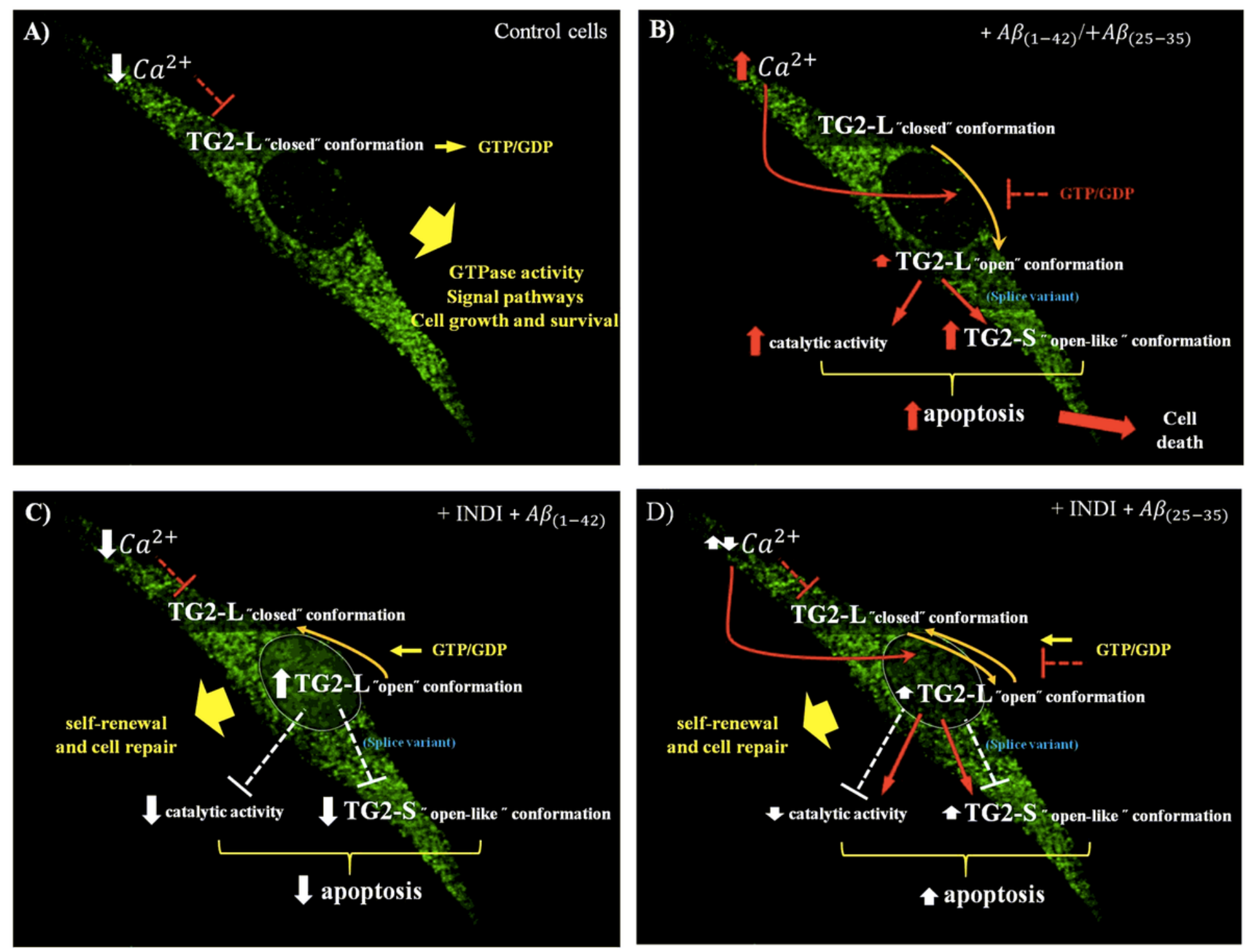

\section{Figure 11}

Drawing regarding the effects of OEC treatments with full native peptide $A \beta(1-42)$ and $A \beta(25-35)$ fragment on TG2 and its isoforms (TG2-L and TG2-S) expression levels both in the absence and in the presence of Indicaxanthin (INDI). (A) TG2-L and TG2-S expression levels in OECs mantained in normal conditions; (B) TG2-L and TG2-S expression levels in OECs exposed to $10 \mu \mathrm{M} A \beta(1-42)$ or $A \beta(25-35)$ for $24 \mathrm{~h}$; (C) TG2-L and TG2-S expression levels in OECs pre-treated with $100 \mu \mathrm{M}$ of INDI and exposed to 10 $\mu \mathrm{M} A \beta(1-42)$ for $24 \mathrm{~h}$; (D) TG2-L and TG2-S expression levels in OECs pre-treated with $100 \mu \mathrm{M}$ of INDI and exposed to $10 \mu \mathrm{M} \mathrm{A} \beta(25-35)$ for $24 \mathrm{~h}$. 